\title{
"THE FIRST BUDDHIST PRIEST ON THE BALTIC COAST": KARLIS TENNISON AND THE INTRODUCTION OF BUDDHISM IN ESTONIA
}

\section{Mait Talts}

\begin{abstract}
Karlis Tennison(s) is an essential, although controversial figure in the history of Buddhism in Estonia and Latvia. He was, without doubt, the first to disseminate Buddhism in the Baltic countries and also one of the earliest disseminators of Buddhism in Eastern Europe. Karl August Tõnisson, born in 1883 near Põltsamaa, Estonia, later repeatedly changed his biography (for example, transformed from an Estonian to a Latvian and simultaneously became ten years older).

The article focuses on the development of his ideas. All his books and other publications, which are modest in volume and usually self-published, were issued between 1909-1916 and 1925-1930. The development of his views can be divided into three main periods: the pre-Buddhist period (before 1911); the 'theosophical Buddhist' period (1911-1916) and the period of ego-Buddhism or neopaganism (1925-1930). Around 1910-1911 Tennison ultimately converts to Buddhism. As he did not identify with any particular school, we may call him an 'abstract' Buddhist. In 1925 Tennison published a book in Latvian and from 1928 to 1930 three books in Estonian. In the publications of this period, Tennison retreats from the principles of Buddhism and allots more space to the glorification of his own personality and to criticism of Christianity, which was typical of neopaganism popular in Europe at the period. One of the most peculiar ideas in Tennison's books is that of the Pan-Baltonian Empire. In that period Tennison also began to disseminate his view that Estonians', Latvians' and Lithuanians' pre-Christian beliefs were somewhat similar to the religious and philosophical systems of India in the Vedic period, which, in the present-day world, are represented in their purest form in Buddhism.

In 1930, Tennison, accompanied by Friedrich V. Lustig, left the Baltics and a year later also Europe, settling for the period 1932-1949 in the Kingdom of Siam. After leaving the Baltics, Tennison did not publish his texts as separate books, although during the last period of his life, in the 1950s and early 1960s while living in Burma, he is known to have been writing his so-called Buddhist Catechism, which remained unfinished.
\end{abstract}

Key words: Buddhism, theosophy, neopaganism, syncretism, syncretic beliefs, Karlis Tennison (Brother Vahindra), book history, history of printed matter

No description of the history of Estonian Buddhism would be complete without the controversial figure of Karlis Tennison(s) alias Karl Tõnisson alias Brother Vahindra, the very first, although probably entirely self-proclaimed Buddhist monk in Estonia. ${ }^{1}$ He was born in the vicinity of Põltsamaa, Central Estonia, 
under the name of $\mathrm{Ka}(\mathrm{a})$ rel August Tõnisson, but already his first books were published under the last name Tennison, which after his acquiring Latvian citizenship was turned into Karlis Tennisons. In this article, he is referred to by the Estonian name variant Tennison as he himself used this form for the longest period. Regardless of the general views towards this historical figure, he played a vital role in introducing Buddhism in Estonia. It is not an exaggeration to claim that over a long period of time, the general views of Estonians on Buddhism were largely supported by several contributing factors proceeding from his personal influence. Of course, the principles of Buddhism were known to the Estonian literati and clergy already before Tennison, and they were probably better acquainted with these than him, but for average Estonians his name became synonymous with a devout Buddhist for decades to come. He was popularly most often referred to as Barefoot Tõnisson even though it was known that he did not always walk barefoot or in sandals only (Mereste 2003: 66).

Brother Vahindra, who was considered eccentric in his homeland, has created a highly original myth of himself, which has continued to have a life of its own. The personal myth of Tennison is one of the finest examples of meme theory: having been launched by him the myth has started to replicate even with the help of people highly sceptical about his person. At the same time one cannot but agree with the claim that Brother Vahindra has become a part of Estonian national folklore (Laane 1983: 27; Au \& Ringvee 2000: 101). The fact that Tennison's personal myth was not forgotten during the Soviet period was in a way further emphasised by the publication of Gennadi Gerodnik's (1973) eloquent book (a satirical documentary narrative in Estonian), entitled Vend Vahindra ('Brother Vahindra'). Gerodnik, naturally, tried to ridicule the "protagonist" of his book as well as Buddhism as a religion, but considering the nature of the period the book still has a positive rather than negative role in introducing the person. In his book, Gerodnik has been rather liberal with history: episodes based on historical facts are linked with fictional interludes and characters, some by Vahindra, and others by Gerodnik. Then again, several claims proposed by Gerodnik have later proved to be true and some presented facts spring a surprise as to how the author could have known such things. Interestingly enough, reports about Gerodnik's book Vend Vahindra spread as far as to Burma. In 1977, Friedrich V. Lustig, a Buddhist monk of Estonian background from Rangoon, wrote to the General Consulate of Estonia in New York that he was well aware of the publication of Gerodnik's books in Estonian and in Russian. ${ }^{2}$

Gerodnik's contribution to elaborating the personal myth of Tennison is all the more important if we consider that in the 1980s and 1990s Tennison's 
Figure 1. Postcard featuring the portrait of young Karl Tennison, Baltica collections of the Estonian Academic Library (dated to around 1912).

personal and spiritual life has not been the subject of serious study and even its mythological aspects have not been explored. Olev Remsu (see 1998) has made some endeavours in this area but even he has approached the material creatively and has not finished what he started. This makes sense, since a serious attempt to reconstruct Tennison's biography even remotely would prove extremely costly and at the same time would not considerably change the general attitudes towards him. The author of this article has attempted to elucidate some generally unknown aspects in Tennison's biography (Talts

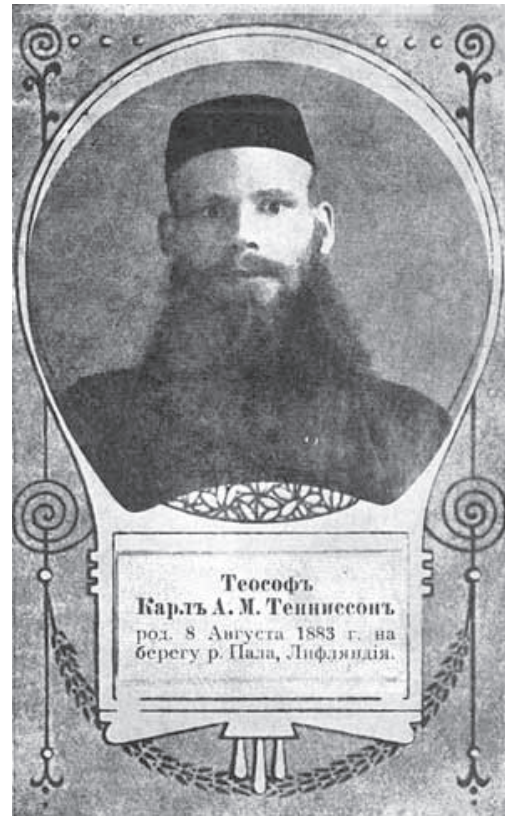
$1998 ; 1999 ; 2002 ; 2003,2004)$, but was also sometimes forced to take into account the "official" views to the autobiography of Tennison. Interestingly, however, other authors have adopted some of the author's views in unaltered form (see, e.g., Raudla 2001) which has, in a sense, also contributed to strengthening his personal myth. In one way or another, Tennison's personal myth is relatively well established by the present day and refuting it would be rather problematic.

In April 2005, an Estonian film group visited Thailand and Burma in pursuit of finding contacts for shooting a documentary on Brother Vahindra and his disciple Friedrich V. Lustig (Ashin Ananda by his Buddhist name). With the assistance of an Estonian Karin Dean who resides in Thailand, they had the opportunity to meet Friedrich Lustig's disciple Maung Aung Khin (U Aung Khin), a resident of Burma. As a result of this expedition, a considerable amount of material of documentary value was brought to Estonia and preparations for the documentary were made (Laurisaar 2005, Pruuli 2005).

Tennison's narratives about his life changed repeatedly throughout his life. His earlier ballads about travels around the world differ significantly from the narratives he told during the period of staying in Latvia (Fišere 1990; 1998). He had added some names to the list of countries he claimed to have visited, and preferred not to mention others that he had reportedly been to. Towards the end of 1930, Tennison and Friedrich Lustig decided to leave Estonia for good. While travelling in Western Europe in 1930-1931, however, Tennison 
had once again changed the story about his background and earlier travels. During the last stage of his life (1949-1962), spent in Burma, Tennison's "official" biography took shape. Long and detailed accounts of his life were published in major Burmese newspapers at the time of his birthday (August 8), which was for some reason always celebrated according to the old calendar. Among other things, these pieces of writing also elucidate some episodes missing in his earlier biographies, such as the world travel with the then heir to the Russian throne Nikolay Alexandrovich Romanov, dissemination of Buddhism among the Nordic peoples, and even Tennison's miraculous escape from the Boxer Rebellion in Beijing around 1900 (see The Nation (Rangoon) 1958; (The Sunday) Nation 1961). Andrew Rawlinson has admitted that scholars of the history of Buddhism, know nothing about Mahacharya Ratnavajra Kunigaitis Gedyminas, a Buddhist monk of Lithuanian background who reportedly ordained Tennison in Burkhuchinsk datsan (= a Buddhist monastery) in Transbaikal (Rawlinson 1997: 619), which seems to suggest that he was a mythological figure.

At the same time we must not rule out the possibility that Brother Vahindra's relation to the so-called objective reality was somewhat different than that of common people. It is certainly difficult to prove, but it seems that Brother Vahindra was simply a person skilled in self-deception. At a later stage in his life he might have actually believed that he was Latvian, ten years senior of his actual age, and had visited all the countries he claimed to have visited. Indeed, after his death an unusual event occurred, for which it is difficult if not possible to find a rational explanation. Even the then prestigious Buddhist journal wrote about the news which spread like wildfire that his body did not show any signs of decomposition over several hot days (The International Buddhist News Forum 1962) and after his death Dalai Lama sent his condolences to his 'successor' Friedrich V. Lustig (The Nation (Rangoon) 1962). News about this spread quickly also to Estonian newspapers abroad (Eesti Päevaleht (Stockholm) 1962; Eesti Hääl 1962).

In any case, Tennison clearly was a remarkable person with a highly unique destiny. The question why this young man from the vicinity of Põltsamaa chose to pursue Buddhist philosophy and promote it "in truth and spirit" has hitherto remained conclusively unanswered. Czech scholar Luboš Belka (1999), who has studied the history of Estonian Buddhism, has even argued that while Germany and the United Kingdom are traditionally perceived as the main migration routes of Buddhism to Europe, Tennison has introduced the third the Baltic route. Even if regarded critically, this view is by no means an exaggeration. Tennison's conversion to Buddhism is, in fact, extraordinary in the entire European context at the time. The view that Tennison was a European 
with the longest "career" in Buddhism is, however, a misconception (Rawlinson 1997: 39). Among Tennison's contemporaries and somewhat younger Buddhist monks, the more important members of sangha (a Buddhist monastic assembly) of even longer period were, for instance, Nyanatiloka (civilian name Anton Gueth) (Rawlinson 1997: 459-461) and Anagarika Govinda (civilian name Ernst Hoffmann) (Rawlinson 1997: 273-278). Furthermore, Tennison cannot be considered the establisher of the first Buddhist Gemeinde in Europe, as has been erroneously claimed at times (Fenzl 1985: 93).

Today, the 'official' version of the life of Karlis Tennisons, created in the latter half of his life, has become almost 'canonized' among devotees of Buddhism in the Baltic countries. The websites and other information materials compiled by Estonian and Latvian lay Buddhists and published mainly on the Internet are entirely based on the myth created during his years in Thailand and Burma, especially regarding the alleged year of his birth 1873 (Buddhist Encyclopedia 2005-2008; Dharmakirjastus n.d.; E-mistika 2007). Quite often the devotees explain that it is the 'legend' that counts in Buddhist tradition, not 'historical truth', which may be arguable.

As a devout Buddhist, Tennison preferred public appearances and direct communication to promote his views, but has also left behind a number of books, brochures and postcards with texts that he sold not only for ideological purposes but also for money.

Since he stayed in Russia during 1917-1923 and in Latvia in 1923-1927, his publishing activities in the Estonian language could be divided in two periods: 1909-1916 and 1927-1930. His publishing activities in the entire Baltic area may be divided in three major periods, which rather nicely reflect the development of his views. These periods could be tentatively labelled as (a) pre-Buddhist period (before 1911); (b) "theosophical-Buddhist" period (1911-1916); and (c) "ego-Buddhist" or neopaganist period (books published during 1925-1930). The most accurately named category is the first. Indeed, the earliest books published by Tennison make almost no allusions to Buddhist philosophy. By 1910-1911 he had already discovered and conceptualised the teachings of Dharma for himself and had started to promote the doctrine in the Estonian and Russian language. He introduces himself as a "theosophist" without having actual relation with the theosophical worldview in particular, which was as such a compilation sewn up of several disciplines with a coarse thread (Mäll 1998: 131). During the third period his unusual syncretic worldview with certain political reservations, though still largely egocentric, is formed, which may be easily interpreted as a mental disorder. At the time, several prolific literati such as Kaarel Leiumaa, Juhan Koritz and Voldemar Kits were active in Estonia; compared to their works, Tennison's texts were quite well rea- 
soned. Like Tennison, Kaarel Leiumaa aspired to step up as a reformer in religious and socio-political issues.

Tennison comes across as a fickle, somewhat mentally unbalanced person, even though he certainly did have more lucid periods. In his recollections, Alf Kubbo describes the "barefoot Tõnu" as a man of sharp wit, presenting rather logical argumentations (Kubbo 1967: 227-232). After Tennison's death, August Kala recounts about his personal contact with him in Tartu at the end of the $1920 \mathrm{~s}$, I was left with the impression that he was a considerate, widely-read and -travelled scholar, who is particularly familiar with the distant past and development of the Estonian people (A. J. K. 1962). Even today there are people in Estonia who remember their childhood encounters with Brother Vahindra with great warmth and regard him as a truly remarkable personality (Jõulu 2003). Such dual attitude is also reflected in his publications of the early period, in which eccentric passages alternate with balanced and objective parts introducing the principles of Buddhism or summarising the history of Buddhism.

\section{THE HISTORY OF BUDDHISM IN ESTONIA BEFORE TENNISON}

Leaving aside the views of Karl Tennison (Tennisons 1954; 1959), who argued that the religion, now known in the world as Buddhism, was spread the Baltic area before the German occupation, it has to be conceded that the first serious people involved in Oriental religions and philosophy were the local Balto-Germans. The Sanskrit language has been taught at the University of Tartu at least since 1837 (Verzeichni $\beta$ 1837: 4); even during the first period of independence in Estonia Oriental languages were taught at the same university mostly by Germans (Hallik 2001a). In fact, from the end of the 19th century until the beginning of the 20th century an array of Orientalists emerged in Estonia, the work and activities of whom is even now little known here. Among the Orientalists more closely involved in Buddhism and Buddhist studies were Hermann von Keyserling (1880-1946) and Alexander Staël von Holstein (1877-1937). The gripping travelogue of India by these two men (Staël von Holstein \& Keyserling 1991) and the anthology of the philosophical essays by Hermann von Keyserling (1998) have been published in Estonian. The contribution of both men to Oriental studies has been extensively studied by Martin Hallik and Olaf-Mihkel Klaassen (Hallik \& Klaassen 2002: 157-160, 178-179). At the same time, Otto Karl Julius Rosenberg (1888-1919), who died at a relatively young age, is virtually unknown in Estonia and his person has started to attract some scholarly attention only recently (see Läänemets 2001). It must be conceded that the influence of Balto-German scholars of Buddhism to the contemporary Esto- 
nian society was rather insignificant and even the first writings of these scholars were translated into the Estonian language only in the late 1980s, when the Oriental studies in Estonia, in search of its roots and looking back to the past, reintroduced them to the general cultural audience (see Keyserling 1989). By the way, in his manuscript book The Mahatma of Baltic, Friedrich V. Lustig (1965:271-274) describes the meeting of Tennison and Hermann von Keyserling, but considering all the circumstances this account is not entirely reliable.

Another important intellectual, although even less identifiable factor influencing the religious scene in the early 20th-century Estonia were the theosophists of St Petersburg and Riga. Theosophy emerged as a counteraction to doctrinal Christianity and, in addition, theosophists took interest in the religious and philosophical tendencies of Oriental origin. Be that as it may, even Karl Tennison calls himself a theosophist in his first books on Buddhism. Tennison most probably was in contact with theosophists in Riga and was likely influenced by analogous spiritual movements in St Petersburg. During the years 1909-1916, Tennison must have travelled quite frequently between Riga and Tallinn and definitely visited, at least a few times, St Petersburg, where the spiritual alternative was offered at the time by active theosophists, anthroposophists and the followers of Gurdjieff. All these movements took greater or lesser interest in Buddhism. At the same time a Buddhist temple was being erected in St Petersburg. News of this event was also broadcast in the Estonian press (Tallinna Teataja 1910). The construction of the temple brought to St Petersburg many Buddhists of Kalmyk and Buryat origin, the best known among these was is Agvan Dorziev, who had initiated the construction (Batchelor 1994: 288-189) and with whom Tennison had reportedly managed to establish a lasting communication. Right before his death Tennison wrote that in 19071915 he was assisting in the construction works of the Buddhist Temple in St Petersburg and the one that "invoke benediction on the materials employed" (Tennisons 1962). It is questionable whether the first meeting of Tennison and Dorziev took place in Astrakhan (Lustig 1965: 162-165) or elsewhere, but they definitely met in St Petersburg on more than one occasion. In addition to his ties with Dorziev, Tennison had reportedly close contacts with the Tundukovs, Kalmyk Buddhists residing in St Petersburg (Andreev 1992: 85). The French writer Alexandre Grigoriantz who has studied the issue from the angle of his personal family history (his grandfather Lucien Ehret hosted Brother Vahindra and his disciple Friedrich V. Lustig during their short stay in the South of France in late 1931) has referred to the possible impact of famous Russian painter and theosophist Nikolay Roerich and his wife Yelena, keenly interested in Buddhism, on the development of Brother Vahindra's conception of the world (Grigoriantz 2004: 88). 
At the same time, some of the factors influencing the spiritual mentality of the first decade of the 20th century have disappeared. Among such key factors, no doubt, was the Tolstoyan philosophy. Count Tolstoy attempted to make his contribution to reforming the Orthodox Church and focused his attention also on other religions, looking for the point of convergence of all religions and the religious philosophy. Books explicating his views were published also in Estonian at the time, and in some of these, Tolstoy mentions Buddhism. Tolstoy was partial to Buddhism as a teaching which puts the spiritual nature of a human first. Here I would like to draw an illustrative parallel. In his essay Mõtteid muhamedi, "buddha" ja ristiusust ("Thoughts on Islamic, Buddhist and Christian faith'), which was published in a booklet in Estonian, Tolstoy writes:

The right philosophy of life is what was taught by the great masters Buddha, Confucius, Lao-Tse, Isaiah and Jesus, and what lies in this understanding that the beginning of life is not material; and my belief in eternal life is based only on this understanding (Tolstoy 1907).

For comparison, here is the tenth "Commandment" from Tennison's book Uchenie o tom, kak chelovek sdelaetsia bezsmertnym:

You shall safeguard this right teaching, given to us by Buddha, Confucius, Isaiah and Jesus. It is on the teachings of these great masters that my belief and eternal life is based on (Tennison 1909b: 48).

In his manuscript biography of Tennison, Friedrich V. Lustig describes at length and in considerable detail (and, no doubt, relying on Tennison's words) one of his encounters with Leo Tolstoy in the latter's estate in Yasnaia Poliana (Lustig 1965: 180-190). It is difficult to establish with certainty whether this meeting actually took place, but the impact of Tolstoyan philosophy on the formation of Tennison's views is quite evident.

Nevertheless, the self-proclaimed Buddhist monk Karl Tennison was not the first person to introduce Buddhism in the Estonian language. As early as in 1895, a popular-scientific booklet entitled Tunnike Buddha templis ('An hour in the temple of Buddha') was published by Postimees ${ }^{3}$ publishers. Regardless of the fact that the book is descriptive and ethnographical and includes some shorter "scholarly" articles not related to Buddhism, it may be tentatively seen as the first publication to introduce Buddhism in the Estonian language. Interestingly enough, the book was published by Postimees, which Karl August Hermann was involved with at the time. He has been mistakenly considered the first Estonian professor of Oriental languages (Belka 1996), and was undoubtedly an amateur sinologist with extraordinary views (Nurmekund 1968: 9-10; Hallik \& Klaassen 2002: 144-148). 
The first book to explore Buddhism in the Estonian language is Buddha, Muhamed ja Kristus ('Buddha, Muhammad and Christ') by German theologian Robert Falke (1903). Like many other works on theological and religious themes at the beginning of the past century, the book was published by Gustav Pihlakas' bookshop. These publications were mostly works of Lutheran authors, and in the early days of the Republic of Estonia also by theosophists (see, e.g., Besant 1924). Since Falke was a pastor, he attempted to compare Christianity, Islam and Buddhism in this comparative-theological book, which was relatively extensive for this period with its 206 pages. Falke relied on the views of liberal theologians of the period, though he eventually was convinced of the "superiority" of Christianity over Buddhism and Islam. He mostly does not contrast the confessions but rather discusses the characteristic features of Buddha, Muhammad and Christ. While his treatment of the principles of Buddhism and partly Islam is more or less balanced and objective, his "evidence" of the superiority of Christianity is based on ad hominem argument. According to his approach, Christ was simply "better", "purer" and "brighter", morally upright, while tales about Buddha (or Prince Siddhārta Gautama before his enlightenment and becoming the Buddha) makes no secret of his carnal and, from the viewpoint of Christianity, sinful nature. Falke claimed that Buddha was simply "a deviant figure". At the same time he concedes that the three world religions share surprisingly many common features.

In fact, Falke's book suggests that the publication of such a relatively extensive treatment of comparative theology in the Estonian language was somewhat premature, which may explain the unexpectedly low sales. Still, even twenty years later, Gunnar Pihlakas' bookstore announces that Falke's Buddha, Muhamed ja Kristus is on sale at the price of 75 Marks (Raamatukogu 1923). The book is notated in the complete catalogue of Estonian publishing market Täieliku Eesti raamatuturu kataloog, which is published five years later and which announces that the book is available at half the price in the book warehouse at the Rahvaülikool publishers (Täielik 1927: 56). Even so, at the beginning of the last century, the spiritual emancipation of Estonians had reached the point where people had become interested in religious and philosophical disciplines other than Christianity. In this period, the Estonian press began to introduce Buddhism and its doctrinal principles (see Uudiste vesteosa 1904; Säde 1906).

Nine years later, in 1912, the book Buddha ja Kristus ('Buddha and Christ') was published in the series of Messages of the Mission by a Sunday paper Ristirahva Pühapäevaleht. Two thirds (pp. 3-13) of the modest volume of this publication is made of an essayistic overview Buddha ja Kristus ('Buddha and Christ') by Joosep Liiv, minister of the Rapla congregation. The overview builds 
on German examples and contains the line of argumentation quite similar to Falke's claims. Buddha's "road of redemption" is believed to be lower, because according to the Buddhist philosophy the spiritual enlightenment depends solely on the person himself, and "redemption" (Nirvana) is attainable only for the chosen (Buddhist monks), and "cessation or extinction" as the ultimate goal cannot arguably replace the bliss of "eternal life" offered by Christ. The author also criticises Buddhism for being a "lifeless" teaching. I doubt that there is anything more tedious to read than the teachings of Buddha, writes Joosep Liiv (1912: 6). In this piece of writing, Liiv reviews the Four Noble Truths, the Noble Eightfold Path and the moral principles of Buddhism quite accurately and without providing his personal evaluation. Thus it seems that the Christian authors of the period no longer considered the introduction of Buddhist principles as harmful for disseminating Christianity as before.

An overview of the literature about Buddhism at the time would be incomplete without the Tibetan travelogue by Swedish explorer Sven Hedin, the first edition of which was published around this time. The travelogue was published in serial form at the end of the first decade of the century and was printed and published as separate volumes (Hedin 1910, 1911). In his short Transhimalaya (Estonian translation Himalaja takka, 1910), written as a thirdperson narrative, Hedin describes in detail a ritual practiced by the Gelug school of Buddhism and very grippingly talks about a hermit monk living in a cave. It is difficult to estimate today the impact of these books to the readers at the beginning of the past century. These travelogues were first fully published in the Estonian language as late as in the 1930s (Hedin 1932,1939) and have not lost their culture-historical significance ever since. Haljand Udam (1998) has noted that even in the mid-1950s and early 1960s, Sven Hedin's books were virtually the only Estonian sources on Tibet.

\section{TENNISON’S ‘PRE-BUDDHIST PERIOD’}

As already mentioned, Tennison was not an inveterate Buddhist by the time his first books and pamphlets were published. By the end of the year 1907, Tennison ought to have settled down in Riga, now capital of Latvia, which became one of the biggest cities of the Russian Empire before the First World War. The earliest of his publications known in these days is a two-page leaflet in large format Meie maakera wiimased minutid ("The last minutes of our Earth'). This piece reflects typical features of Christian eschatology, while making an attempt to invent a somewhat 'personal', unorthodox approach including some implication to 'pagan' predictions. The leaflet was printed in Tallinn, in 
Ehrenpreis print shop, but the text itself was obviously written in "Riga, October 15, 1907" as indicated on the leaflet.

The first book by Karl Tõnisson, Tennissoni elulugu: Luuleteel 306 salmi ('Tennisson's life story: poetic career of 306 verses') is clearly eccentric in approach and peculiar in literary style. The book was published parallelly in Tallinn and Riga as separate editions, which suggests that already during this period Tennison travelled between these two cities quite frequently. In this book of poetry in the style of the post-awakening period, Tennison describes in what now seems somewhat comic doggerel verse the adventures of his life so far in the form an imaginary world travel. The book opens at the port of Riga and leads him through Africa and Australia to India and through China, Siberia, Turkey and Palestine to South-America, from where he returns to Europe. According to a popular belief, the world travel described in this book is a pure fiction (Kaasaegne 1962). As a matter of fact, nothing in the book yet suggests that Tennison will be a Buddhist. In his doggerel he only appears as an 'abstract' Christian, and once or twice mentions Jesus as his idol (Tennisson 1909a: 6). He claims that his religious beliefs are based mostly on personal conviction and therefore do not imply performing ritual practices. At the same time Tennison criticises pastors and priests as distorters of true religion and speaks of himself as a person who has had to suffer for his beliefs a great deal.

In 1909, Tennison's second book Uchenie o tom, kak chelovek sdelaetsia bezsmertnym ('A teaching of how to immortalise a human', Tennisson 1909b) was published in Russian in the Budberg print shop in Riga. In this book, Tennison propagates a rather peculiar philosophy - namely, he promises to teach the youth of his time how to live forever and consoles the older generation that even they might live at least 200 years, if they follow his teachings. In this rather peculiar manner he embeds Christian views on morality with a liberal rendition of evolutionism. According to Tennison's approach at the time, eternal life should be relatively easily attainable, but only if the aspirer returns to the state before the Fall of Man. He thereby relies on a passage in the Book of Isaiah in the Old Testament and a few passages in the Genesis, but he also mentions Buddha and Confucius as his mentors (Tennisson 1909b: 48). Even later, in his interviews in the written press, Tennison has promised to live at least 200 years (Vaba Maa 1927a). Interestingly, around the same time there was another intriguing person in Estonia who dreamed of living 200 years and according to whom it was possible by practicing healthy and morally upright lifestyle. This person was Nikolay von Glehn, the "Mad Baron" and founder of the town of Nõmme. 


\section{THE ‘THEOSOPHICAL-BUDDHIST PERIOD’}

Around 1910-1911, Tennison becomes a devout Buddhist and begins to advocate Buddha's teachings in speech (Ajaleht 1913) and in publications. The period of 1911-1916 can thus be characterised as highly prolific in his publishing activities. Including reprints, he published at least five books on Buddhism in the Estonian language, one book in Russian and a bilingual book in Estonian and Russian during this period. In his manuscript biography of Tennison The Mahatma of Baltic, Friedrich V. Lustig refers to these books as "Buddhist pamphlets" (Lustig 1965: 279). The written press at the time also mentions the "Buddhist catechisms" that he spread (-am-1916), the title probably derived from that of his newest publication at the time (Olcott $1916 \mathrm{a} / \mathrm{b})$. In addition to these books, Tennison published smaller booklets and postcards promoting himself around this time. It is likely that not all of these have been preserved, or are held in private archives. Richard Majak (1975: 68) mentions in his recollections a postcard from this period.

Disseminating the Buddhist principles becomes a highly important activity for Tennison at the time. Tennison, however, does not identify himself with any specific branch or school of Buddhism. Paraphrasing the concept "abstract Christianity" we could very well speak of Tennison as an "abstract Buddhist" who has not attempted to define his position among the various schools of Buddhism. But even the West-European scholars of Buddhism at the time made no clear distinction between the schools of Buddhism and regarded the tradition of Tipitaka, the Pali Canon, the only "true" Buddhism (Mäll 1998: 134). Even today such attitude is quite common. According to the 2000 national census there were 622 persons in Estonia who considered themselves Buddhists. It seems that this relatively large number refers to the situation in which most of these people simply regard their personal conception of the world as Buddhism (Põlenik 2004: 67).

Olaf-Mihkel Klaassen has quite aptly described Tennison's views as "Budomania" (Klaassen 1990: 38). It is interesting to note that the egocentric attitude which was so characteristic of him later in his life is not very prominent in his activities of this period. Then he introduced himself as "a member of a group of monks disseminating Buddhism" (Tennison 1913a), not as the "first Buddhist monk on the Baltic coast" as has become traditional in the most recent books in Estonian about him. As to his personal history, it is remarkable that in nearly all his books of this period, Tennison has repeatedly insisted that he was born "in 1883 on the bank of the Paala River in Livonia", although later (since his opting for Latvian citizenship) his new "year of birth" 
is dated ten years earlier, to 1973 , and this date is widely spread in the literature about the history of Buddhism (Rawlinson 1997: 619; Batchelor 1994: 291292). Archive materials confirm the validity of the former date. ${ }^{4}$ Even more so - in the books of this period Tennison appears relatively tolerant towards other religions, especially Christianity, while hints of his "struggling anti-Christian" views begin to emerge in his later books (e.g., Tennison 1914).

From the same period there are indirect (and somewhat vague) reports about some other books published by Tennison around this time, but for some reason these books have not been accessible for Estonian libraries and are therefore not included in the Estonian National Bibliography. For example, the deputy censor of Tallinn H. Jannsen alludes in his letter to the public prosecutor of the Tallinn District Court on March 18, 1913, to one of his earlier complaints about a calendar published arguably by Tennison in 1912 (Depman 1927: 15). It is possible that the censor confuses Karl Tennisson with Mats Tõnisson, a reputed calendar publisher at the time. The 1912 calendar of the latter indeed exasperated both the Governor of Estonia as well as the local clergy, which is why some of the publications were collected and destroyed. ${ }^{5}$ Indeed, in the correspondence of the censorship office in the Russian language the name of Mats Tõnisson is transcribed as Tennison (Матс Теннисон), as has been transcribed the name of Jaan Tonnisson, editor of the newspaper Postimees

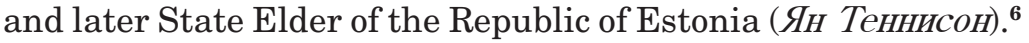

It has also been claimed that yet another Estonian "book of poems" by Tennison was published in 1912 or 1913 in the Laakmann print shop, or according to other information in Bergmann print shop (Mengel 1962). Although it has been mentioned a few other times (Gerodnik 1973: 33-34; Teder \& Mõttus 1993), nothing is known about the fate of the publication. The correspondence of the Tartu censor contains no reference to this book. Still, it cannot be entirely ruled out that the book was published, since one Tennison's book which is listed in the Estonian National Bibliography - Igavene mälestus suurest Ilmasõjast, millest mina Karl Tennisson osa võttin ('Eternally remembering the Great World War which I, Karl Tennisson, took part in'; Tallinn, 1915) - has so far not been found as a separate publication.

Tennison's first book about Buddhism was the Estonian and Russian bilingual book Suur meister Buddha ja tema kõrge moraliline õpetus ('The Great Master Buddha and his noble moral teachings'; Tennisson 1911a). The book, characteristic of the period, was published two years after his literary debut. In this book Tennison emerges as a devout Buddhist. I am Finnish by birth and Buddhist by religion, he declares on the title page. Tennison's high-flown style, which became highly characteristic of him later, also starts on the title page: he claims that he can survive 40 days without food, run 12 hours without 
stopping, eat a spoonful of "cholera bacteria" and is immortal. The same message of four-five sentences on the title page, which functions as the book's cover and features a photo of young Tennison, nude above the waist, is used also in the design of his second book published within the same year (a ballad in Estonian Inimene, 'The man', Tennisson 1911b). Both books were printed in Tallinn in print shop Keyler ja poeg and are rather eclectic in appearance. Richard Majak's memoirs indicate that before the First World War Tennison was selling postcards at markets and fairs, the texts of which were derived from the title pages of his books Suur meister Buddha... and Inimene, and which probably featured the same photo motive (Majak 1975: 68).

By now the book Suur meister Buddha ja tema moraliline õpetus has become such a rarity in Estonian libraries that not a copy of it can be found. The only known copy is held in the National Library of Russia in St Petersburg. The book, in fact, consists of three parts: a short preface containing information about his life history ( $3.5 \mathrm{pp}$ ), a two-page narrative verse with the title Tükike minu elust ('A piece of my life') and a part introducing the main principles of Buddhism. Regardless of the egocentric opening, almost half of the book introduces a balanced and authentic overview of prince Siddhārta's becoming the Buddha and the introduction of the main principles of Buddhism, which is remarkable in that it is the first attempt to disseminate Buddhist ideas in Estonian by a devout Buddhist author (especially since Falke's book was rather opposed to Buddhist teachings).

In the biographical preface in prose form, Tennison describes the more or less similar fantasy world travel as in the verse biography published in 1909, and is occasionally even more superficial in doing so. He also makes obvious mistakes, confusing some countries which he supposedly had visited. At the same time it appears that his book reflects a certain turning point in the development of Tennison's views. In the first two parts, Tennison himself speaks of his religious pursuits rather than directly mentioning Buddhism. This is only natural, since the verse narrative $A$ piece of my life was written during his Buddhist period and its Estonian translation has been published in the book Uchenie o tom, kak chelovek sdelaetsia bezsmertnym. In this work of poetry, Tennison still addresses God as his Master, which suggests that both the poem as well as the biographical preface have been written considerably earlier than the last part of the book, which is a review of the chrestomathic truths of Buddhism.

A considerably more intriguing work of poetry is Tennison's highly original Inimene ('The man', 1911b), in which the author makes an attempt to express his philosophical views. In this poem, which has a somewhat better verse rhythm and metrics but is still rather unprofessional, Tennison attempts to formulate 
his understanding of the man and his place in the universe. By doing so he embeds Buddhist truths with Taoist influences and the Western pantheistic philosophy of nature. In this work of poetry Tennison emphasises the temporality of the attempts of all humans and the uselessness of emotions. According to Buddhist views, humans like other sensuous beings are the intermediary products of the eternal cosmic game of the joining and diverging of Dharmas (the smallest basic units of the world). Like Chinese Taoists or Ancient Greek philosopher Heraclitus, Tennison claims that nothing in this world is stable and everything is in constant movement. Specifically, owing to this cycle of matter, energy and spiritual substance, humans are able to join the Universe and sense the entire process. In any case, the poem Inimene is one of the most unique and interesting books in the creative work of Tennison. The book has also become a rarity by now and for a long time it was believed that not a single copy of it has been left. The retrospective Estonian National Bibliography referred to the book through secondary sources (Eestikeelne 1993: 850), but in 1998 the Estonian National Library managed to get hold of a copy of the book.

The third Buddhist book by Tennison Mikspärast Buddha usulised juutide Talmudi ei usu? ('Why can't Buddhists believe in Jewish Talmud?'; Tennisson 1914 ) is also the first book which clearly reflects his anti-Semitic and antiChristian attitudes. Regardless of the few anti-Semitic statements by him, the book still remains a polemical work and the author "in truth and spirit" proceeds to confute Christian truths. For the first time Tennison declares that Buddhism is based on scientific understanding. Buddhism or Buddha's teaching is a science and we, the Buddhists, explore the science and revere nature, he writes on behalf of millions of Buddhists and makes a reference to the theory of evolution as well as the cause and effect of the laws of Karma. In the work of poetry Mälestuse laul ('The song of memory') created for his 30th birthday and published in the final part of the book, Tennison admits that even he has once advocated the "babble of Jews" in his religious frenzy, but has now understood the lack of perspective in doing so. In addition to the polemisation which gave the book its title and the poem, the book also provides a rather straightforward overview of the arrival of Buddhism in Europe. Tennison focuses on the spread of Buddhism in Germany and the United Kingdom, but also mentions the Buddhists of Switzerland and Hungary, providing the names of Germans Karl Seidenstücker and Walter Markgraf, who were the first to introduce Buddhism in Germany (Baumann 1995: 54-56). He also mentions British T. W. Rhys Davids and Gordon Douglas (the latter was probably the first European to be ordained a Buddhist monk (Batchelor 1994: 41). Interestingly, in his later biography, which he published during his Latvian period, Tennison claims that he 
was accompanied by the same Gordon Douglas on his world travels (Fišere $1990 ; 1998)$. The book is one of the best-designed works by Tennison from this period, especially compared with the conventionally eclectic layouts full of typographical components of other books of the period. The designer of the stylish late art nouveau framing on the book's pages and the person to choose the fine artistic Gothic script is not known. The book is printed in the print shop of J. \& A. Paalmann, which was famous for its tasteful art nouveau book designs.

As was already mentioned, during this period Tennison also published a book introducing Buddhism in Russian. In 1916, the book Buddizm: Drevneindiiskaia religioznaia filosofia $i$ ego evoliucia $v$ Evrope $v$ nashi dni ('Ancient Indian religious philosophy and its development in Europe in our time') was published in M. Schiffer's print shop in Tallinn (Tennisson 1916b). In this book, Tennison includes under the title Kratkaia istoriia veliikago uchitel'ia Buddy ('The short life history of the Great Master Buddha') the Russian text introducing Buddha's life and the principles of his teachings, which were published in the already mentioned Suur meister Buddha ja tema kõrge moraliline õpetus. The second chapter of the book about Buddhism in Europe (Budizm v Evrope) is a rather matter-of-fact and informative overview of the ideological pursuits related to Buddhism in Europe at the time. This chapter is basically analogous to the text published in Miks Buddha usulised juutide Talmudi ei usu?, though it extends the geographical bounds of the approach to America and also takes a look at the contribution of theosophists like Annie Bessant and Henry Steel Olcott in disseminating Buddhism among Europeans.

The last publication of this clearly distinctive "theosophical-Buddhist" period is Tennison's only translation. This a book with a long title Budda usu katekismuse esimene peatükk, I mida Zeiloni saare ülempreester H. Sumangala läbi kutsunud ja heaks kiitnud. / Eestikeelde trükkida lasknud Budda usuline munk Karl Augustus Mihailovitsh Tennisson ('Chapter One of the Buddhist Catechism that H. Sumangala, Grand Priest of the Ceylon Island, has tested and approved / Published in Estonian by Buddhist Monk Karl Augustus Mikhailovich Tennisson',Olcott 1916a/b). Like Tennison's debut, this book was also published parallelly in Tallinn and Tartu as two separate editions (see Olcott 1916a/b). Essentially, the book is a somewhat abridged translation of the first chapter of the popular Buddhist catechism by American theosophist Henry Steel Olcott (1832-1907).

The first edition of Olcott's book in English was published already in 1881. Olcott, who had a Protestant upbringing, called his work a "catechism" on the example of the Christian works and focused in his book on the Pali Canon in Buddhism. Hikkaduwe Sumangala, Hinayana priest of Ceylon, had indeed studied it but did not agree with everything that Olcott, who was influenced by theosophy, writes in his catechism. Tennison's book includes only the first 
chapter of Olcott's catechism, which accounts in the form of simple answers and questions the life of Prince Siddhārta Gautama and his becoming the Buddha and the Four Noble Truths (which Tennison translates into Estonian as neli tõsidust, or 'four earnest truths'). These are the underlying truths of Buddhism, the interpretation of which can hardly be erroneous. It is mostly the final chapters of the catechism, however, that are debatable, as here Olcott attempts to deconstruct the relations of Buddhism and science from the theosophical viewpoint (Rawlinson 1997: 466), but these chapters are not translated in Tennison's publication.

Tennison has added to the first chapter of Olcott's book the already mentioned "Ten Commandments" of Buddhism from his book Suur meister Buddha ja tema kõrge moraliline õpetus. To the edition published in Tallinn, Tennison added a chapter of rules according to which only Buddhist priests have to live. The edition published in Tartu, featuring an entirely different layout, includes the preface which is missing in the Tallinn edition and entirely coincides with the first chapter of the book Mikspärast Budda usulised juutide Talmudi ei usu? ['Why can't Buddhists believe in Jewish Talmud?']. As a matter of fact, only one copy of the Tartu edition with the first chapter of Olcott's catechism on a loose sheet printed on one side is known and it is held in the Estonian Literary Museum. The copy has a dedication by printer Hermann to the censor for asking him to be kindly acquainted with it and is dated to February 5 , 1916, suggesting that the book was probably not granted the final publishing right. The draft manuscript also contains the title page to the publication Igawene mälestus Suurest Ilmasõjast, millest mina Karl Augustus Mihailowitsh Tennisson wabatahtelisena osa wõtsin ('Eternally remembering the Great World War which I, Karl Augustus Mikhailovich Tennisson, volunteered for') and a poem of 1,000 verses entitled 1000-salmiline lugulaul, millest 980 salmi peale sõja avaldatud saab with a note about the war censor's approval from September 7, 1915 (dozvoleno voennoiu tsensuroiu Revel, 7 sentiabria 1915 g.) (Olcott 1916a: 15-16). The identical poem with the identical promise that 980 verses will be published after the war can be found on a rare leaflet of different layout, the only copy of which remains in the possession of Mart Orav (Tennisson 1916d). Such unfulfilled promises are quite characteristic of Tennison even later in his life.

Olcott's catechism was one of the most popular books introducing Buddhism at the time. Already by 1897 the catechism had been translated into 20 foreign languages (Rawlinson 1997: 465), including German and Russian. Since Tennison was next to the Estonian language most proficient in Russian, it is highly likely that his translation is based on the Russian translation of the book, although translating from the German version cannot be entirely ruled out. It 
is worth noting that another Estonian translation of Olcott's Buddhist catechism was made through the mediation of the Finnish language 70 years later on the initiative of the semi-underground Estonian Buddhist Brotherhood (Rootalu 1990: 47). As late as at the end of 2002, H.S. Olcott's Buddhist Catechism, through the mediation of Finnish, finally appeared in the Estonian language for the first time (Olcott 2002).

The Tallinn edition of the first chapter of Olcott's catechism probably had the widest circulation among Tennison's books. It was on sale even as late as in 1927-1928, but the print run was beginning to run out by then (Tallinna 1927: 68). Other books published by Tennison during the same period (19111916) have become very rare by now.

In addition to books, Karl Tennison also made living by selling small prints and postcards, mostly dedicated to his own person, although some of them are interesting in tracing the development of his views. Libraries and archives hold a random number of pamphlets and postcards. Secondary sources seem to suggest that the number of such small prints and postcards in circulation was considerably larger. Of the small printed pamphlets, two single-sheet prints from 1913, one of which is in Estonian (Tennisson 1913a) and the other parallelly in Russian, Latvian and Estonian, are held in the archive collection of the Estonian National Library.

The former of the leaflets has been printed in the print shop of W. Wolkmann (former Keyler ja poeg) in Tallinn and was issued to celebrate the opening of Theatre Estonia. There are two short poems on this leaflet: Suurel pidustuse päeval 1913 Tallinnas ('On this great day of celebration in 1913 in Tallinn') and Risti usust Buddha usku astunud eestlaste hymnus ('Hymn of Estonians who have converted from Christianity to Buddhism'). The latter prompted H. Jannsen, censor of Tallinn, to file a complaint to the District Court of Tallinn to confiscate the leaflet on the grounds of undermining the fundamentals of Christianity. By doing so, censor Jannsen relied most likely on the confidential circular by the State Committee for Publishing from the beginning of 1913, which saw the reporting of published materials not exactly forbidden but extremely biased and harmful from the aspect of religion and state as well as morality (Issakov 1983: 219-220). The court council's ruling issued on March 23, 1913 was negative in this case and reasoned the decision with the fact that the poem under discussion is nothing but accumulation of meaningless phrases (Depman 1927: 16). The poem, however, is of consequence from the aspect of the development of Tennison's views, since here he refers for the first time to the link between prehistoric paganism and Buddhism.

The second of the mentioned leaflets has been printed in Riga and includes the "Ten Buddhist Commandments" already mentioned in relation to Tennison's 
Suur meister Buddha... in the language used in the then Livonian guberniya. Four of these "commandments" are a part of the five basic morality precepts that lay Buddhists are supposed to observe (see Baumann 1999: 30-40). Of these precepts Tennison has neglected the one about refraining from alcohol and other intoxicants. Even though Tennison's "Ten Commandments" have been inspired by the Christian Ten Commandments, they are still very much the result of Tennison's creative thinking.

In addition to these leaflets and some prints in larger format, at least three small prints in postcard format connected with Tennison are known from this period. The earliest of these is a postcard with a photo of Tennison and a short poem in the collection of Ülo Matjus, supposedly dated to the period 1908-1911 (his 'pre-Buddhist period'). The postcard depicts a rather widely used motif of Tennison wearing the student uniform, an image that is also used as an illustration in Tennison's biography (Tennissoni elulugu) and Suur Buddha ja tema kõrge moraliline õpetus. The poem Laul Tormilinnust, ehk minu elust ('The Song about the Storm Bird, or My Life') bears semblance to the poetic work A piece of my life in the above book. Here, too, Tennison speaks of "God as his Master" for following whom he has had to suffer. The poem Laul Tormilinnust ehk minu elust was apparently re-printed on several occasions. In the Baltica collections at the Academic Library of Tallinn University there is a unique one-page leaflet with the canonic tanka image of Lord Buddha and the photo of young Tennison with the same poem dated to 1916 (Tennisson 1916c).

The copy of Tennison's book Buddizm ('Buddhism') has a printed photo the size of a postcard but on a thin paper glued inside the front cover (possibly by Tennison himself). This small printing product is entitled $V$ pamiat Veliikoi Voiny ('Remembering the Great War'), it has been printed in the print shop of J. \& A. Paalmann and has a comment in Russian, approved by the Tallinn war censorship on July 25, 1916 on it. The book itself was printed in Schiffer's print shop and has been granted the publishing rights by the Tallinn war censorship on June 7, 1917. Another analogous printed material preserved is a postcard from 1914 with an art nouveau framing in the possession of Erik Arro, a publisher of Buddhist literature. The postcard, which has no image on it, but features one of Karl Tennison's patriotic poems, in which he declares the fall of the German Empire which started after the First World War. Two postcards with the portrait of Tennison are held also in the Baltica collection of the Estonian Academic Library: one is the same motif with the art nouveau ornamentation, which is duplicated on his leaflets and the title page of his book Mikspärast Buddha usulised juutide Talmudi ei usu ['Why can't Buddhists believe in Jewish Talmud?'], whereas the second dates back to the second half of the 1920s and is Tennison's photo portrait (Fig. 1). 
According to Hamilkar Mengel (1962), Tennison was selling a poem printed on a coated paper in Ahja, his home region, around 1915. This could have been a copy of Igavene mälestus suurest Ilmasõjast, millest mina Karl Tennisson osa võttin ('Eternally remembering the Great World War which I, Karl Tennisson, took part in'), which has not been found so far. Astonishingly, Mengel is able to cite a part of this poem almost fifty years later, which seems to suggest that the printed material must have been available to him at the time or at least at his disposal for a longer period of time. The lines quoted by Mengel largely coincide with the poem 1000-salmiline lugulaul, millest 980 salmi peale sõja avaldatud saab, published as an appendix to the Tartu edition of Tennison's Budda usu katekismuse esimene peatükk ('Chapter One of Buddhist Catechism', Olcott 1916 a).

The Estonian readers thus experienced for the first time the Estonian-language literature introducing Buddhism towards the end of the Tsarist period and even more so since the beginning of the 1920s. This first acquaintance took mainly place owing to the activities of Karl Tennison, but was also furthered by some publishers of missionary literature with Christian views. During the end of the Tsarist period (1901-1917) the total of at least 8,673 books and other printed materials were published in the Estonian language. 1,092 of these (constituting almost every eighth) were of theological content (Annus 1993). The seven books of rather modest volume, which in one way or another introduce Buddhism, constitute a tiny part (less than 0.6 per cent) of all the religious and theological literature of the period, but even then Buddhism was the best represented confession in the corresponding repertoire of Estonians at the time. This enables us to assume that in Estonia Buddhism was at least better known than any other Oriental religion.

\section{THE ACTIVITIES OF KARL TENNISON DURING THE INDEPENDENT REPUBLIC OF ESTONIA}

In his books published during 1911-1916, Tennison simply advocated the principles of Buddhism and sometimes introduced the spread of Buddhism and predicted its future developments in Europe at the time. On the other hand, in books published after his return to the Baltic countries (1923) he already proclaims his somewhat changed personal worldview. However, Tennison was and still is best known for his two books in Estonian language that were published at the end of the 1920s, since the books published during the Tsarist period were already rarities and falling into oblivion during the first period of independence in Estonia. These two books are Tulevane Pan-Baltoonia Ilmariik ja 
selles kuldses riigis asuvate Buddha-, Päärkonsi-, Pikse- ehk Taarausu preestrite seadus ('The future Pan-Baltonia and the law of Buddhist or Taara priests in this golden state', Vend Vahindra 1928) and Mina ja minu jüngrid usume nõnda ('Me and my disciples believe so', Mahatma Vend-Vahindra 1930). The third book in Estonian published during this period and entitled Hom-Mani-PatmeHung (Tennisons 1927) may be regarded as the draft of the first book, which he never managed to buy out from the book depository and distribute (Mengel 1962).

Regardless of the comicality of his books in some respects, they have later been considered ideologically dangerous. The police chief of Võru County has arguably reported to his superiors in Tallinn after the publication of the books Tulevane Pan-Baltoonia Ilmariik... and Mina ja minu jüngrid, implying to the threat the ideas expressed in these books pose to the regime established in Estonia (Gerodnik 1973: 89). Despite this incident, Tennison's books were not censured in the 1930s as "dangerous literature" like some other publications which were considered "confusing but causing social anxiety" (such as Inimkonna Internatsionaal or 'The Internationale of Mankind', Tallinn 1933, 4 pp.) and Üle-eestimaaline harmoonilise riigikorra loomise rahvaplaan ('All-Estonian people's plan for establishing a harmonious rule of government', Tallinn 1933, $4 \mathrm{pp}){ }^{7}$

In the Soviet period, however, it was considered necessary to include the above titles by Tennison in almost all lists of forbidden literature (Hariduse Rahvakomissariaadi Teataja 1940; Raamatukogudest 1963: 160; Raamatukogudest 1966: 145-146).

Karlis Tennison returned to Estonia after ten years abroad in 1927 (Rahvaleht 1927). Tennison himself mentions the same year in his books (Vend Vahindra 1928: 6-7). Some sources reveal that reportedly he was in Estonia (and in Tallinn) already in 1926 (Lustig 1965: 429). Before that he definitely had settled in Latvia for a while, where he published the book Ko Buddas priesteris Tennisons grib dot latvju tautai? ('What Buddhist priest Tennison wishes to give to the people of Latvia', Tennisons 1925), which was intended as the first volume of the extensive 25 -volume series (Fišere 1998). The book continues the tradition of his booklets published in Estonian before and during the First World War. In addition to the short introduction to the basics of Buddhism and the history of Buddhism inherent to his scriptures of that time, the book also describes in more detail his newly established Buddhist shire in his appartment in Baložu Street 8, Riga. These days the house looks quite the same as in the photograph published in the book. Many pages in that modest book are dedicated to arguments with his real and imaginary opponents. 
In his Tulevane Pan-Baltoonia Ilmariik... Tennison claims that he has advocated the idea of Pan-Baltonia since July 1926 (Vend Vahindra 1928: 63).

Since these two books are largely self-congratulatory, Tennison's views of the period could be tentatively labelled as 'egobuddhism'. While in his earlier books he was still probing to create his personal myth, at times even distancing from it, then since the end of the 1920s his personality steadily emerged on the foreground. This may lead to the somewhat justified question whether Tennison can even be considered a Buddhist in this period. Tennison identifies himself as a "philosopher", "astrologist", "scholar", "literary man with a golden and durable quill", "rare idealistic sportsman" or, for example, "artist of sauna, whisking and steam", once even "a certified God of sports and philosophy and health" (Mahatma Vend-Vahindra 1930: 15-16). (Towards the end of his life while Tennison was living in Burma, being an entirely respected citizen, he again abandons the egocentric motifs in his writings.)

Around this time, the second cornerstone of his later worldview - neopaganist syncretism - is being developed. His beliefs are clearly linked to neopaganism, rather popular in the 1920s, which was represented by the Tannenberg League in Germany and most expressly by Taara-believers in Estonia. In his book Mina ja minu jüngrid usume nõnda, Tennison repeatedly refers to himself and his followers as "neopagans". In the books of this period, Tennison thus represents the new syncretistic line of thought, which is the result of the merging of paganism and Buddhism, but which still lacks an independent and clearly distinctive system of concepts. He therefore speaks about Buddha's death as the travel of his spirit to "Baro-Nirvana" to join Pikne ('Thunder')(Vend Vahindra 1928: 11, 25; Mahatma Vend-Vahindra 1930: 14) and expresses other such spiritual "amalgamations". He does not, however, speculate much further.

One of the most distinctive features in Tennison's activities of this period is his clearly anti-Christian pathos. The first reports of the conflicts between Tennison and Orthodox monks come from the period before the First World War (Majak 1975: 67-69). At the time, Tennison acted as an ironic mocker rather than a devout and unrelenting opponent of Christianity. On the other hand, during the period of the first Republic of Estonia, he attempted to wage war on Christianity in almost all his publications and public speeches. Even more so, he associates Christianity with Judaism, but also with theosophy, which he identified with Freemasonry, Mussolini's fascism and many other movements of the time, at least by name (Vend Vahindra 1928: 28).

Towards the end of the 1920 s, Tennison first came out with his theory according to which the prehistoric religion of the Baltic peoples (Taara-believers in Estonia and Thunder-believers in Latvia and Lithuania) is a special form of basic Buddhism. Tennison took to introducing this view in his public speeches 
at the time (Vaba Maa 1927b) which occasionally involved the pagan rituals of prehistoric Estonians, Latvians and Lithuanians (Vaba Maa 1929). Later, while living in Thailand and Burma and returning to the origins of Buddhism, Tennison held on to and even tried to elaborate this idea (Tennisons 1954, 1959; Eesti Päevaleht (Stockholm) 1960). Like Taara-believers at the time (see Hiis 1931), Tennison emphasises that his belief is developing and relies on "common sense" and advances in "science". At the same time he emphasises his opposition to "Jewish mythology", under which he includes not only Christianity and Judaism but also Islam. In his Tulevane Pan-Baltoonia Ilmariik... Tennison declares that

the Buddhist priests do not believe in things that are unacceptable and not understandable for common sense and unexplained by serious science (Vend Vahindra 1928: 14).

In his book Mina ja minu jüngrid usume nõnda he claims:

I'm a biologist and a biocosmist and the only representative of the Buddhist philosophy and natural science on the Baltic coast, and also an astronomer and astrologer and knowledgeable in the system of Mother Son, the elemental force of all the elemental forces of life, and the scholar of distant cosmic space (Mahatma Vend-Vahindra 1930: 8).

It is also known that during his stay in St Petersburg at the beginning of the 1920 s, Tennison was in contact with the active literary group which called themselves biocosmists (Kruus 1983: 69-70). Biocosmists attempted to connect the principles of futurism with science, but relied on their romanticised views on science and its role in the society.

A new tendency in Tennison's activities at the time is his search for a way of "political expression" to his views. Thus his idea of the "neo-absolute-monarchist" theocratic Pan-Baltonia, with Buddhism as the official religion, is born. According to Tennison, in Pan-Baltonia there would be plenty of room for all peoples and ethnic groups in the world, except the parasitic Jews and Armenians (Vend Vahindra 1928: 18). The official religion of Pan-Baltonia would be Buddhism reformed by the restitution of the mythology of the Baltic people and the official language would be Russian (as a language equally understood by all Baltic peoples), which, however, would be written in Latin alphabet (probably also for the sake of clarity). However, Tennison delineates the boundaries of the future Pan-Baltonia outside the Baltic States. According to him, PanBaltonia would stretch from the Neva River and Lake Onega to Köningsberg (Mahatma Vend-Vahindra 1930: 11). 
A copy of the said book is held in the personal registry of Kaarel Robert Pusta in the Estonian State Archives, ${ }^{8}$ with an inscription inside the front cover in French by Tennison alias Brother Vahindra (Charles Tennisons alias Frêre Vahindra) to Pusta, then Estonian ambassador in France. The inscription is dated to January 8, 1931 and is written in the handwriting of Friedrich V. Lustig, Tennison's disciple, who was much more proficient in French than Tennison. Since Pusta was known as a person closely associated with the PanEuropean movement, giving the books as a present may be seen as an implication by Tennison, the author of the idea of Pan-Baltonia, to certain "parallels" between the two rather different political ideas.

Quite a substantial part of the book Tulevane Pan-Baltoonia Ilmariik... is filled with what Tennison calls the series of photographing or picture album Some photos in this series were published already in 1927 in Hom-Mani-PatmeHung (Tennisons 1927) and it appears that Tennison's original intention was to issue the picture album as a separate publication (Esmaspäev 1927). The 37 pages contain shorter or longer comments on photos depicting Brother Vahindra posing with younger men whom he refers to in captions as his "disciples". At the same time it is known that several of these young men have later publicly protested against this (Vaba Maa 1927a). And, conversely, there have been cases in which Brother Vahindra himself has been misled. He has, for example, appeared on a photograph with a young man who calls himself Prince Papaver-Somniferum, the name of whom stands for 'opium poppy' in Latin (Vend Vahindra 1928: 78). Evidently, this conscious misleading represents an ironic allusion to Karl Marx's statement, frequently quoted by Bolsheviks, that religion is the opium of the people.

The book Mina ja minu jüngrid usume nõnda, which was published in Estonian and printed in Eduard Bergmann's print shop in 1930, remained the last separate publication by Tennison. In this, Tennison leads the narcissist worship of his person to the logical conclusion, identifying himself as Mahatma Vend-Vahindra (Mahatma Brother Vahindra) on the example of Mahatma Gandhi, who was extremely popular at the time. Speaking of himself in third person, he declares on the first pages of the book that even though he has lived through many evil, distressing and painful years ... he feels no signs of weakness or aging (Mahatma Vend-Vahindra 1930: 2; and again in the photo caption: Vend Vahindra 1928: 74). In the book, Tennison elaborates his vision of PanBaltonia and the unity of prehistoric religions in the Baltic area and criticises Christianity as "the mythology of Jews". I don't believe in the resurrection of dead bodies, corpses or carcasses, or repentance of sins, Tennison declares (Mahatma Vend-Vahindra 1930: 10). 
Even in this period, Tennison had postcards and possibly also leaflet-like minor publications printed to show off his personality. The best known postcard of Tennison which depicts the "uncovered physique and beauty" of Tennison on 13 photos and a central portrait is held in the Cultural History Archives at the Estonian Literary Museum (see Talts 2003: 1424). The same set of photos is printed on the first page of his book Mina ja minu jüngrid usume nõnda. A postcard with a painted portrait of Tennison (by painter A. Jurich) dated to 1928 can be found in the personal collection of Erik Arro. This postcard has also been printed in Tennison's book Tulevane Pan-Baltoonia Ilmariik... (Vend Vahindra 1928: 2). Other postcards featuring his portraits from this period and with the same photo caption in content and form are known (one, for example, donated to the autor by Eedo Jõesaar, see Fig. 2).

Recurrent images in Tennison's books seem to suggest that he used to carry the printing cliches of his books and postcards with him, probably with the intention to publish new editions of his books after he had settled in a new country. Newspaper articles reveal that when Tennison crossed the LatvianEstonian border in Valga in August 1927, the Estonian border patrol confiscated the printing cliches of his books among other "contraband" (Vaba Maa 1927a). In any case, he reportedly had made a deal with a publisher in Tallinn to issue a brochure in Estonian (Esmaspäev 1927). The brochure under discussion is most likely his book Hom-Mani-Patme-Hung (Tennisons 1927) which was published also in 1927 by the Varrak publishing house in Tartu. Both the text and the illustrations of this booklet are essentially a "draft" for the book Tulevane PanBaltoonia Ilmariik..., which was published a year later in Riga. The front page features a photograph of Tennison reading a bulky volume in the

Figure 2. The text on the postcard is written in Estonian and Latvian and translates into English as 'Karlis Tennisons alias Brother "Vahindra", the first Buddhist priest on the Baltic coast, the famous "barefoot" and member of "Sangha", the order of Tibetan friars, citizen of the Republic of Latvia'.

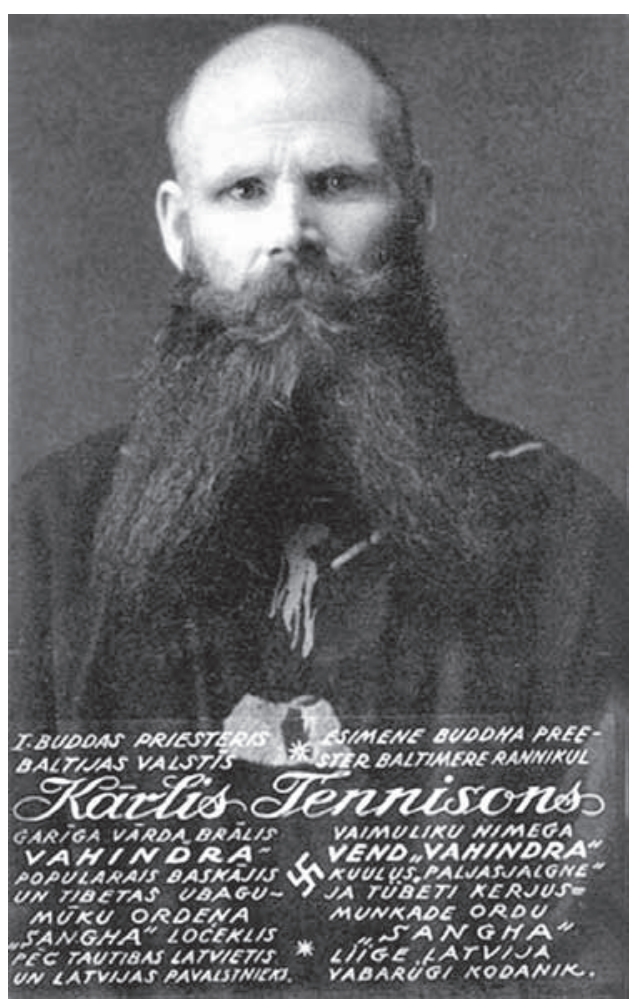


library; the same photo has also been published in the written press (Rahvaleht 1927). This newspaper article is one of the most positive reports of Tennison's activities which are otherwise rather ironically covered in Estonian newspapers (Fig. 3). Tennison, however, did not manage to distribute the book HomMani-Patme-Hung, since reportedly he did not succeed in buying the books from the depository of the Varrak publishing house (Mengel 1962). Three known copies of this book are currently held in the archival library of the Estonian Literary Museum in Tartu. Since the book was listed in the register of complimentary copies of printed products at the police department of the Ministry of Internal Affairs, ${ }^{9}$ the three copies held in the Literary Museum are very likely the complimentary copies that arrived there through this channel.

While reading Tennison's books, one may begin to wonder where he acquired his knowledge of Buddhism that he so creatively corrected with personal views later in his life. Journalists who visited Tennison noticed already in the 1920s that he had collected a remarkable library in his apartment in Tartu, which included rare manuscripts from Mongolia (Postimees 1928b). It has been established that Tennison himself had not read original Buddhist texts, although, probably during his stay in Russia, he had

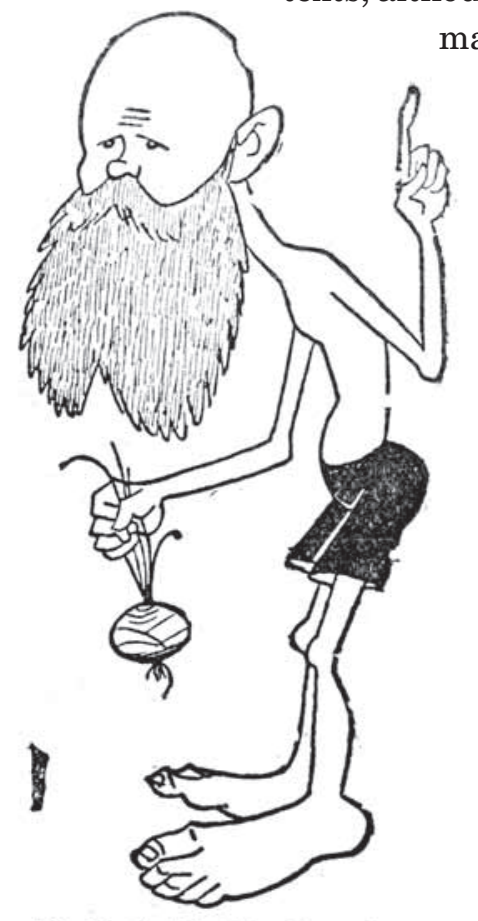

Prohvet Karlis Tennisons. „Kui olete te haiged, ja tervis on schvahindra,

Siis terveks teha võib teid ainult venđ Vahindra!“
Figure 3. Caricature caption: Prophet Karlis Tennisons. If you're sick and your health "schvahindra", you can be cured only by Brother Vahindra. (Gori 1930). 
Tennison and Lustig themselves believed that they were exiled because of an article they wrote about Tibet (Stockholms-Tidningen Eestlastele 1950) and because of their political views that diverged considerably from the views of the allegedly Japan-minded government of Phibun Songkhram. Which Tennison's books exactly were confiscated will probably never be known.

It is quite impossible to adequately determine the acceptance of Tennison's books and thus his views in the society at the time. Even though his person was quite renowned, it is difficult to establish in which numbers were his books bought and read. At the end of the 1920s, there was only one article announcing the publishing of his book among the otherwise abundant material published in the written press about him, and even this article focuses on the scandal with photo captions printed in the book (Esmaspäev 1929). It may be speculated that he was often viewed as a somewhat comical figure (a typical "village mystic" as Linnart Mäll has so aptly put it), who sometimes excited sympathy and on rare occasions certain respect for his persistence in his beliefs. His peculiar idea of Pan-Baltonia was the only one to elicit certain response, and even that was straightforwardly ironical (Edasi 1927). In any case, the attitude of the general public towards him was by no means as ironical as is reflected by the written press, which focused mainly on the person of Tennison rather than his views. For that reason, the attitudes towards Tennison could sometimes be surprisingly positive. On the occasion of his death, Aleksander Simm, for example, has compared Karl Tennison with statesman Jaan Tõnisson:

Let's call out to our brother, Buddhist priest, who died in Rangoon, in eternal commemoration, because he was one of the Estonians who treated his country, his people and his language with respect and, whenever possible, tried to do good for Estonia (Simm 1962).

More often than not, Tennison was the object of ridicule or outright parodizing (see, e.g., Vaba Maa 1920).

The Estonian written press at the time repeatedly published the claims that at some point in his life, the sales of his books and postcards was Tennison's only

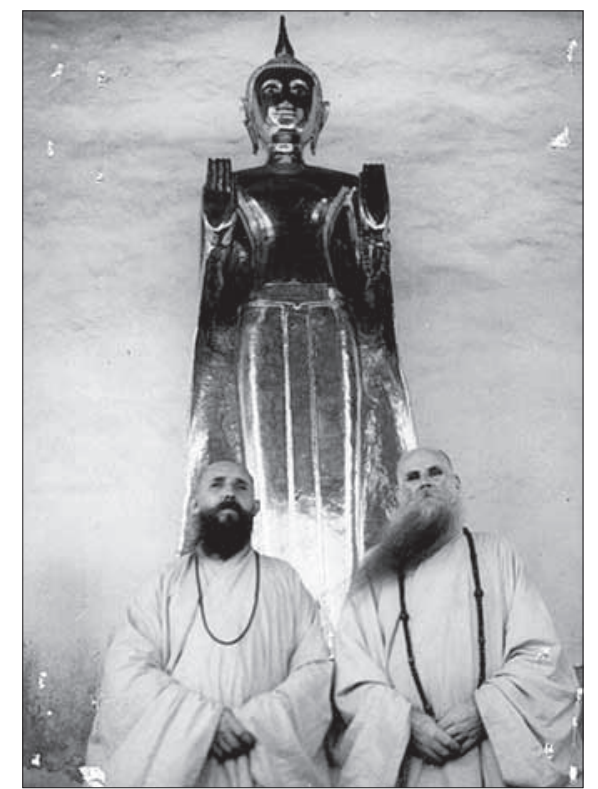

Figure 4. Karl Tennison and his disciple Friedrich V. Lustig in Thailand in the late 1940 s. 
subsistence (Uusleht 1916; Rahvaleht 1925), implying that Tennison's publications must have sold quite well at times. According to newspaper articles, Tennison sold his book Mina ja minu jüngrid usume nõnda at the price of 25 cents per piece and despite the relatively high price (as the paper suggests) the books were quite popular (Oma Maa 1930). In any case, Tennison himself declares on the blurb of his book that his other book, Tulevane Pan-Baltoonia Ilmariik, is available at the price of only one kroon. Roman Karu, who lived in Kadriorg, Tallinn in the summer of 1930, recalls that he once heard Tennison, passing by his window and telling his disciple Lustig that we will split the profits. ${ }^{11}$ It is very likely that this comment also regarded the profits of book sales.

It is also known that Tennison must have had enough money to print advertisements announcing his public appearances (Teder 1973). The author of this article has had access to a printed material in the size of a smaller poster, which is held in the collection of bibliophile Eedo Jõesaar, and which advertises the public appearance of Brother Vahindra in Viljandi at the same event that Juhan Teder has mentioned in his article. However, texts printed on this poster by no means match the texts on advertising leaflets distributed at the event and as quoted by Juhan Teder. Tennison, thus, probably had means to print more than one advertisement for each of his public appearance.

It is likely that people bought his books as curiosities, without taking the ideas he advocated too seriously or thinking too deeply about authentic Buddhism, the foundation of Tennison's views. Therefore it may be assumed that the pagan pathos of his religious convictions was somewhat more popular. Apparently, the movement of sun worshippers which was instigated by Antoni Kalamees in the mid-1930s in Karksi (Vaba Maa 1935) may have been inspired by Tennison's books.

Tennison's contemporaries recall that he tried to advocate his views mostly among young men of tender age (Tonska 1962; Kubbo 1967: 227-232; Niitme 1983: 226, 228-229), which has later been the source of various speculations. It is known that sometimes he even addressed small children to disseminate his beliefs. For example, Olaf Imelik describes an incident in his early childhood of Tennison prophesising to him on Toome Hill in Tartu that Imelik would be the devout disciple of "the first Buddhist monk", which somehow later became true (Imelik 1998: 122). Tennison often tried to make his convictions heard by anyone who bothered to listen, given the circumstances. It is also known that Tennison had preached Buddha's teachings to people waiting for their return to homeland in the resettlement commission in St Petersburg (-il- 1921).

In fact, Tennison's eccentric personality and scandalous public appearances have overshadowed the contents of his religious preaching. Tennison remained 
such an exceptional character in Estonia that he could not find congenial characters, except for his only true disciple Friedrich V. Lustig. It is known that other young men with spiritual interests communicated with him at times. In his manuscript biography of Tennison, Lustig (1965: 446) mentions the names of Vene, Weber, Napritson and Rumvelt as his disciples, while none of these young men became regular disciples. There is also a poem inside the back cover of Tennison's Mina ja minu jüngrid..., authored by someone called Karlis Lomp. A person by this name was at that time a student of Valga Russian Gymnasium and later a student of theology and philosophy at the University of Tartu and also a member of student fraternity Fraternitas Tartuensis (Album 1994: 218). It is impossible to claim with absolute certainty that this was the same person, but it is quite likely.

Perhaps the most renowned temporary "satellite" of Tennison was Vladimir Rooberg (Roopere), who was a law student at the time he communicated with Tennison and later an attorney representing Farmers' Unions and small holders in the 5th Riigikogu (Parliament of Estonia) and for a short period held the position of the Minister of Internal Affairs and Courts in the government of Jaan Tõnisson (Eesti 1939: 234). When Tennison made a public appearance at the beginning of October 1993 in the "Bürgermusse" society in Tartu, Rooberg tried to evade the imposed entertainment taxes and use most of the event's profits to cover his personal debts (Postimees 1927b; Vaba Maa 1927c). Rooberg later tried to deny the allegations against him (Raoberg [!] 1927) but even years later the affair was brought up on his running to the Estonian Parliament by newspaper Vaba Maa (1932). Bibliophile Olaf Esna has also mentioned the name of his relative circus artist Mihkel Esna as Tennison's one time companion (Esna 2006).

Tennison's preaching was somewhat more effective in Latvia, which is confirmed, for example, by the fact that he managed to find staunch followers among Latvian intellectuals. Aleksandrs Janeks, professor of Colloid Chemistry at the University of Latvia, was one of the few devout Buddhists in Latvia in the early 1920s. After Karlis Tennisons' first public appearances, Janeks publicly criticised the first Buddhist monk on the Baltic coast for his disregard of Buddhist principles (see also Janeks 1924). In his newspaper interviews, Tennison himself has occasionally mentioned that he had established somewhat better relations with Latvians (Vaba Maa 1930). After his final departure from the Baltic area, Tennison often sent letters to Latvian newspapers rather than Estonian ones, which summaries the latter eagerly published (Päevaleht $1932 ; 1933)$. On rare occasions he sent his postcards and letters directly to the editors of Estonian newspapers (Vaba Maa 1931). 
It has to be remembered that during the most active period of his activities at the end of the 1920s, Tennison no longer represented authentic Buddhism, as he did during his earlier ("Buddhist-theosophical") period, but advocated mostly an eclectic synthesis of Buddhism and neopaganism. Thus we may agree with authors who believe that the activities of Tennison (at least during this period) distanced people from Buddhism rather than promoted the dissemination of Dharma teaching. This by no means minimises his significance as the first preacher of Buddhism in Estonia, especially in the second decade of the 20 th century (years 1911-1916). It was mostly owing to Tennison that Buddhism became more widely known in Estonia and in other Baltic countries and perhaps raised interest towards authentic Buddhism. Tennison also visited Lithuania in 1926 (Postimees 1928a), but the effect of his preaching there remained rather modest. It has been claimed on the basis of rumours that in the 1950s, some Germans interested in Buddhism encountered in Thailand a Buddhist nun of Lithuanian origin who claimed to have been Tennison's disciple (Frenzl 1985: 100). Most likely the nun was a German Jew Margot Markuse from Riga, who was living in Thailand at the time and was ordained a nun there. It is also possible that Tennison and Markuse might have met in the mid-1930s in China, which they both visited at the time (Hecker 1997: 192193; Uus Eesti 1936), but there is no evidence to back this up. It is certain, though, that Margot Markuse could not have been Tennison's disciple.

\section{OTHER BOOKS ON BUDDHISM DURING THE FIRST PERIOD OF INDEPENDENCE IN ESTONIA}

Karl Tennison, the self-proclaimed Buddhist monk, was not the only disseminator of Buddhism in Estonia at the end of the 1920s. Around the same time a couple of books of considerable importance introducing Buddhism were published and greater interest towards Oriental philosophy, including Buddhism, was taken at the University of Tartu. The introduction of Buddhism, however, did not have a very far-reaching effect in Estonia during the period between the world wars, and this, in a way, popularised Tennison's role as a "religious prophet" among the general public of the time.

In 1924, the book Loomad, inimesed ja jumalad ('Beasts, Men and Gods') by Ferdinand Ossendowsky (1924; translated into Estonian by Ella Jung and issued by the Estonian Publishing Society in Tallinn) was published. This book could be considered typical in that it had an important role in introducing Buddhism but was not directly related with the conceptual field of Buddhism. 
This is actually a historical adventure novel, set in Mongolia at the time of revolution and the central character is a half-legendary Robert (Roman) von Ungern-Sternberg. The personality and the peculiar fate of Robert von UngernSternberg, who came from Estonia and was mythologised as the Defender of the Law of Buddha (dharmapala), has inspired many writers and scholars. Estonian author Olev Remsu has written quite a few books on him, though only one of these might be considered a short study (Remsu 1999).

In any case, Ossendowsky's book attracted more serious interest in Buddhism. Friedrich V. Lustig has repeatedly emphasised that the descriptions of this particular book aroused greater interest in him and eventually led to his conversion and joining the Sangha (Lustig 1965: 441; Listopadov 2000). Also, Estonian translator and Orientalist Haljand Uudam has mentioned the possibility of treating the work as a Buddhist book of awakening (1997). Be that as it may, the book was one of the first works to present a clearer view of Buddhist practices for the Estonians than the former books by Tennison or the approach by pastor Falke, which was written in the spirit of Christianity and was trying to put the Christian religion first at all costs. In a way, the book's popularity is also attested by the fact that Erik Arro's publishing house Buddhakirjastus (now Dharma Publishers) published the second edition of the book (under the somewhat pretentious title Kommunism või elav Buddha 'Communism or the Living Buddha') in 1996, and the third edition in 1997 under the restored original title.

Additionally, two rather important books presenting quite an expert approach to the principles of Buddhism at a comprehensible level were published towards the end of the 1920s by the Sõnavara publishers in Tartu. These two books are Kristus ja Buddha 'Christ and Buddha' (Aunver 1925) by Jakob Aunver (1891-1985), ${ }^{12}$ minister of the Jüri congregation and a long-term editor of the newspaper Eesti Kirik (Estonian Church), and Buddha ja tema õpetus ('Buddha and his teachings', 1929) by Carl Theodor Strauss (1852-1937) ${ }^{13}$ of Swiss-German-Jewish origin.

The book by Jakob Aunver (1925), which was published in J. Mällo's printhouse in Tartu is based on the juxtaposition of Buddhism and Christianity and therefore reminds of Falke's book Buddha, Muhamed ja Kristus ('Buddha, Mohammed and Christ', 1903). The book relies on Aunver's candidate's thesis that he defended a few years before (see Postimees 1923). Aunver had published single extracts of this study in periodical Eesti Kirik (Aunver 1924), indicating that he was familiar with the main views of his contemporary disseminators of Buddhism and particularly tried to refute the theory of Subhadra Bhikshu (Friedrich Zimmerman), which claimed that before turning thirty, 
Jesus had lived in India where he was taught by Buddhist teachers. Like Falke, Aunver is eventually convinced in the superiority of Christianity, but only on the last pages of his book, as prior to that, Buddhism and the life of its founder is treated with remarkable respect for a staunch Christian and verger. The author of this article has come upon a single short introduction in the newspaper Eesti Kirik, which was edited by Aunver himself (de-K 1925). It is possible, though, that it was Aunver's book in particular that aroused the interest in Buddhism among the academic circles in Estonia. For example, it is known that in 1927, issues of Buddhist ethics were discussed on the meeting of the Academic Theologians' Society (Postimees 1927a).

In the light of introducing authentic of Buddhism, however, the book Buddha ja tema oppetus by Strauss (1929) is much more consequential. The book provides a rather thorough but at the same time popular overview of the teachings of Buddha, and became a weighty alternative to Tennison's books which no longer represented authentic Buddhism at the time. Carl Theodor Strauss was the pupil of Anagarika Dharmapala, who was of half-Sinhalese origin and was active in the United States, and he was also considered the first contemporary secular Buddhist in the Western World (Rawlinson 1997: 244). In this book which was published by the Sõnavara publishers and printed in Eduard Bergmann's print shop in Tartu, Strauss attempts to disprove misinterpretations about Buddhism. Buddhism is treated as an independent phenomenon and the comparison with Christianity is completely lacking. The author provides a rather thorough overview of the life of Buddha and the basic principles of his teaching. The book was first published in the German language in 1921, while the first edition of the book was published in Switzerland in the international constructed language Ido (Hecker 1997: 339). Before the translation was published in Estonian, the book had already been translated into English and Czech. The identity of the Estonian translator, who is referred to only by initials K.M., remains unknown. According to the lexicon of pseudonyms by August Palm, one of the users of these initials was Kusta Mannerma (Palm 1960), but he translated mostly from French. ${ }^{14}$ The preface by the translator reveals that the translation is with omissions, which may partly explain the translator's wish to keep his or her identity secret.

The overview of the repertoire published during the first period of independence would not be complete without the two volumes of Ceylon travelogue Palava päikese ja fanaatilise usu maal ('On the land of hot sun and religious fanatics') by Karl Rumor-Ast (1930), in which the author, among other things, discusses Buddhism, the dominant religion on the island. Rumor-Ast wrote his travel letters in midstream (mostly in hotels and sometimes even on the train) and some of these were published in Estonia even before his return. Despite 
the title, the author admits the tolerance of Buddhism towards other religions and points out the basics of Buddha's teaching. Shame on you who are struggling in your heart attached to earthly fruit. Be human, but become godlike. Learn to live without desires, so that you could die without remorse and fear, he writes in his book (Rumor-Ast 1930: 76).

Regardless of all, Karl Tennison remained a highly exceptional phenomenon in Estonian cultural history. During 1909-1930 he published at least 16 books (including new editions): 13 in Estonian, two in Russian and one in Latvian. Of these 16, eight in Estonian, one in Russian and a book in Latvian were directly or indirectly connected with Buddhism. Of the books in Estonian, six were original works and two were translations (or, to be more precise, two different editions of the same book). Regardless of his wish to stand in opposition with and criticise Christianity, Tennison's Buddhist books followed the example of Christian missionary literature. Yet, it may be claimed that all his books are "collage-like" in structure in that they consist of various parts, which sometimes are related to the topic of the book but at other times are rather loosely connected. These parts have probably been written at different times, and, as it appears, in different states of mind. Next to Tennison's ambition to be the Defender of the Law, his books are characterised by his poetic aspirations since almost all his books include interludes in poetic form and shorter ballads. Tennison's poetry has been published in several newspapers and periodicals in Estonia (Tennisson 1916a) and Latvia (Tennisons 1924). His poems changed very little in time (cf. Tennison 1916a and Vend Vahindra 1928: 42-43).

Interestingly enough, the ideas proposed by Tennison have influenced at least one person who is closely connected with Buddhism today - Erik Arro, a publisher of Buddhist literature, who had a slightly different background than Tennison but has sympathised with Tennison's oppositional pathos to Christianity and Judaism. Arro (1994) has quite decisively criticised the barbarian past of Christianity. In 1993, Buddhakirjastus published the slightly revised new edition of Tennison's Tulevane Pan-Baltoonia Ilmariik under the title Tulevane Buddhistlik Balti riik ('The Future Buddhist Baltic Country'), which features two prefaces by the editor (Vend Vahindra 1993). About three pages of text, or article 24 of the Law of Priests, in which Tennison discusses the role of Russian language in future Pan-Baltonia, have been omitted in the book (pages 31-34 in the original), which is rather unfortunate. A pertinent comment or concluding remarks would have, perhaps, minimised the "discrediting" passages. 
Regardless of all, Buddhism still remained a rather "foreign" and distant, at best an exotic and mysterious and even somewhat romanticised line of thought both in the Republic of Estonia and contemporary Europe. Considering that the number of titles of books published in the Republic of Estonia between the world wars was 25,000-30,000 (Liivaku 1995: 122), the 6-7 books representing or discussing Buddhism at the time is a very small number indeed. One relatively weighty explanation for that, as has been noted, is a prejudice, quite popular and naturally supported by Christian theologians, according to which Buddhism represents pessimism and aspired to avoid any activity of mind (Mäll 1989). Consequently, authentic Buddhist philosophy has attracted the interest of only the narrow circles of intellectuals and even that without any regard to the activities of Tennison. Estonian author and literary theorist Valmar Adams and renowned linguist Paul Ariste were allegedly among those interested in Buddhism in the 1920s-1930s. It has been said that Adams was also involved in meditation, which he repeatedly referred to as "autogenic training". Gennadi Gerodnik (1973: 70-71) describes in his book at greater length a meeting of Valmar Adams and Brother Vahindra, which may have actually taken place, considering all the circumstances.

At the same time, Gerodnik's book has given rise to an ungrounded legend. Namely, he claims that according to the 1934 census, there were only three Buddhists in Estonia, the best known of who was novelist August Gailit, who had jokingly listed himself as one (Gerodnik 1973: 80). In fact, the statistics of the 1934 census show that there were at least 20 people ( 15 men and 5 women) who defined Buddhism as their religion in Estonia (Rahvastiku 1935: 120-121). The majority of Estonian Buddhists at the time resided in Tallinn, but some also in Narva, Narva-Jõesuu, Elva, Nõmme, the Võru County and elsewhere. It may be speculated that at least some of them, but not all, were Kalmyks living in Estonia. As it has been established, the devout Buddhists Tennison and Lustig had already left the country by this time.

Except for the fascinating travelogues by Sven Hedin $(1932,1939$, the first book translated by Jakob Aunver) and an extract from Helena Blavatsky's The Voice of the Silence (1939), which treated Buddhism indirectly and "creatively", it has to be agreed that in the final decade of the period between the wars (1930-1940) virtually no books directly about Buddhism or introducing Buddhism were published in Estonia. At the same time, however, the first indirect translation of Lao-Tse's Dao-De-Džing (1937) was published by enthusiasts, and interest towards Oriental cultures surged among the academic circles at the University of Tartu. According to a little known fact, in the final years of the period between the world wars, some people interested in Oriental philosophy founded the Academic Oriental Society at the University of Tartu. The society 
was established at the end of 1935 and the first president of the society was Eduard Vigel, with Leo Leesment and Uku Masing as members of the board. The society united people whose main line of interest remained outside the Oriental studies. This is also the reason why the society's activities never gained wider popularity and were only modestly covered in the local press at the time (Uus Eesti 1935; Päevaleht 1936; Vaba Maa 1936). During 1935-1939, the Academic Oriental Society held altogether 35 meetings, at which 20 thorough reviews and presentations were held (Päss 1939: 73).

According to the newspapers, two volumes of proceedings of the Academic Oriental Society were ready for publication already in the autumn of 1939 (Päevaleht 1939). Uku Masing's work Prohvet Obadja etioopiakeelne tõlge ('Prophet Obadia's Ethiopian translation') was intended as the first publication of the society, but it never appeared in print (Hallik 2001b: 219). The second and only issued publication of the Academic Oriental Society was the offprint of Eduar Päss's article about the religious beliefs of Ingrians and Votes, published in autumn 1939 (Päss 1939), which had previously appeared in the annals of the Learned Estonian Society. Although the blurb of the publication informs that the first issue of the society's proceedings has been "formerly" published, this must have taken place not earlier than in 1940. As evidence of this, a dozen draft copies of this issue, featuring the preface in Estonian and French by professor Leo Leesment, president of the society, are held in the office of Oriental studies at the University of Tartu. The following comment has been added on the margin of the draft copies, Nationalised K. Mattiesen's print shop, ltd., Tartu 1940. The facsimile of the two-page draft copy has been reproduced in an issue of Sonumitooja ('Messenger', 1990: 3), published by the Academic Oriental Society and the same text has been published in international scholarly periodicals by Czech scholar Luboš Belka (1996: 404), who has also studied the history of Buddhism and Oriental philosophy in Estonia. The materials which were already prepared for publication at K. Mattiesen's print shop were most likely destroyed. Regardless of that, the activities of the Academic Oriental Society in the period 1935-1940 left an indelible mark in the cultural history of Estonia. In any case, the society offered institutional support to famous Estonian scholar Uku Masing to take up serious research in Oriental philosophy and culture.

The history of learning Buddhist principles and teachings in Estonia is little over a century old. It has followed a rather peculiar course with setbacks and longer periods of standstill owing to external circumstances. Many, often diametrically opposed figures have acted as pioneers on this path. The course was first undertaken by some Balto-German literati, whose influence on the budding Estonian intelligentsia was insignificant. Then emerged Karl Tennison, a 
self-proclaimed ardent and devout disseminator of Buddhism, who was sometimes even tagged insane, but who became highly visible for the general public. By the 1930s, Tennison had already left Estonia. This period witnessed the rise of interest in Buddhism in the academic circles at the University of Tartu, but the Second World War and Estonia under various occupying powers reversed the course for decades. For this particular reason, Karl Tennison alias Karl Tõnisson alias Brother Vahindra has been given a special place in the history of Estonian Buddhism.

Translated by Kait Tamm.

\section{ACKNOWLEDGEMENTS}

Special acknowledgements to Liivi Aarma, Erik Arro, Maie Barrow, Stephen Batchelor, Martin Baumann, Luboš Belka, Karin Dean, Alexandre Grigoriantz, Hellmuth Hecker, Eedo Jõesaar, Roman Karu, Mare Kõiva, Nikolay Listopadov, Ülo Matjus, Mart Orav, Tiit Pruuli, Vallo Raun, Andrew Rawlinson, Aarand Roos, Tae Hye, Kait Tamm, Liisa Vesik, and Peeter Vähi.

\section{COMIMENTS}

1 The most recent publication on the topic is a popular overview by Pruuli \& Vähi (2007: 246), in which the history of Buddhism in Estonia begins with the name of Karlis Tennisons.

2 Friedrich V. Lustig's letter to the General Consulate of Estonia in New York from February 8, 1977. In possession of the author.

3 Major Estonian daily, published since 1886. Editor's note.

${ }^{4}$ Estonian archives of vital statistics: Perekonnaseisuarhiiv, f95, n 1, s 2492, 1 21, entry no. 200; Estonian Historical Archives (EAA) 1168-1-211, p. 176.; Siseministeeriumi RTO 95-1-2525c, p. 176.

5 See Estonian Historical Archives (EAA), f 52, n l, s 620.

${ }^{6}$ See Estonian Historical Archives (EAA), f 321, n 1, s 215; s 211, $125-45$.

${ }^{7}$ See Estonian State Archives (ERA), f 852, n 2 s 568.

8 See Estonian State Archives (ERA), f 1622, n 2, s 110. 
9 See Estonian State Archives (ERA), f 1, n 7, s 249, I 119.

${ }^{10}$ Friedrich V. Lustig's letter to the General Consulate of Estonia in New York from January 31,1950 . In the possession of the author.

${ }^{11}$ From personal communication with Roman Karu in summer 2002.

12 On Aunver see Veem 1988: 389.

${ }^{13}$ On Strauss see Hecker 1997: 338-339.

${ }^{14}$ It has to be noted that Estonian literary theorist Eerik Teder considers Mannerma the most likely translator of the book (from personal communication with Eerik Teder).

\section{REFERENCES}

Ajaleht 1913. Kole põrutav kõne. [Highly shocking speech.] 18 Nov, p. 3.

A. J. K[ala] 1962. Paljajalgne Tõnisson: Mälestusi ühest omapärasest isiksusest.[Barefoot Tõnisson. Memories of a singular person.] Vaba Eestlane, 21 July, p. 6.

Album 1994 = Album Academicum Universitatis Tartuensis 1918-1944, 3. Tartu Ülikooli 1929-1944 immatrikuleeritud üliõpilased. Matriklinumbrite 10192-19954. Rohuteaduse kuulajad. 1918. aasta II semestril immatrikuleeritud üliõpilased. [Students accepted at the University of Tartu during 1929-1944, listed under numbers 10192 19954. Students attending pharmaceutics lectures. Students accepted for second term in 1918.] Tartu: Tartu Ülikooli Kirjastus.

-am- 1916. Postkaardid Tallinnast: Madame Thébe: Buddha preester. [Postcards from Tallinn: Madame Thébe: Buddhist priest.] Tallinna Teataja, 14 July, p. 3.

Andreev, Aleksandr Ivanovich 1992. The Buddhist Shrine of Petrograd. (Andreev A. 1992. Buddiiskaia Sviatynia Petrograda.) Ulan-Ude: EcoArt Agency.

Annus, Endel 1993. Eessõna. Eestikeelne raamat 1901-1917 [Estonian book 19011917.] Tallinn: Eesti Teaduste Akadeemia, pp. 6-13.

Arro, Erik 1994. Satanismi juured - budism või kristlus? Päevaleht, 22 Sept, pp. $12-13$.

Au, Ilmo \& Ringvee, Ringo 2000. Kirikud ja kogudused Eestis. Tallinn: Ilo.

Aunver, Jakob 1924. Kas Kristus või Buddha? Eesti Kirik, 17 Jan, 24 Jan, 31 Jan, 7 Feb, 14 Feb. Tartu.

Aunver, Jakob 1925. Kristus ja Buddha. Tartu: J. Mällo.

Batchelor, Stephen 1994. The Awakening of the West: The Encounter of Buddhism and Western Culture. London: Thorsons.

Baumann, Martin 1995. Deutsche Buddhisten: Geschichte und Gemeinschaften. Marpurg: Diagonal-Verlag.

Baumann, Martin 1999. Kompass Buddhismus = Compass Buddhism. Hannover: LVH.

Belka, Luboš 1996. Oriental and Buddhist Studies in Estonia. Archiv Orientální, 64, pp. 399-404. 
Belka, Luboš 1999. Buddhism in Estonia. Religion, State and Society, 27 (2), pp. 245-248.

Besant, Annie 1924. Elu mõistatus teosoofia valgusel. Tallinn: G. Pihlakas ja poeg. Original: A. Besant 1911. Riddle of Life-And How Theosophy Answers It. Anand Gholap.

Blavatsky, Helena P. 1939. Väljavõtteid "Kuldsete õpetuste raamatust”. Tallinn. Original: The Voice of the Silence: being chosen fragments from the "Book of the Golden Precepts." London, New York: The Theosophical Publishing Co. Ltd. 1889.

Buddhist Encyclopedia 2005-2008 = Budismi Entsüklopeedia - Eesti Njingma. Available at http://nyingmapa-buddhism.no-ip.org/, last accessed on 14 Apr 2008.

de-K 1925. Vaimuliku kirjanduse alalt. [On clerical literature.] Eesti Kirik, 18 June, p. 192.

Depman, Jaan (ed.) 1927. Kellega kah Eesti tsensorid sõda pidasid 1907-1914. Eesti kirjandusloo ained Vene isevalitsuse arhiivides. Sankt Peterburg: Külvaja.

Dharmakirjastus n.d. Available at http://www.hot.ee/dharmakirjastus/pildid/, last accessed on 14 Apr 2008.

Edasi 1927. Uus keiser - või- ja piiritusekuningate asemel. [New emperor replacing butter and spirit kings.] 4 June, p. 4.

Eesti 1939 = Eesti riigi-, avaliku-ja kultuurielu tegelased 1918-1938. [State, public and cultural figures in Estonia in 1918-1938.] Tallinn: Eesti Kunstnike Liit.

Eesti Hääl 1962. Sensatsioon Karlis Tennisonsi laibaga. [Sensation with the dead body of Karlis Tennisons.] 28 Sept, p. 3.

Eestikeelne 1993 = Eestikeelne raamat 1901-1917, 1-2. [Books published in Estonian language 1907-1917, Vols 1-2.] Tallinn: Eesti Teaduste Akadeemia.

Eesti Päevaleht (Stockholm) 1960. Baltimaade sidemed budhismiga. [Ties with Buddhism in the Baltics.] 23 Nov, p. 2.

Eesti Päevaleht (Stockholm) 1962. K. Tennisons võeti budausu pühakute nimekirja. [K. Tennisons enlisted as a Buddhist saint.] 26 Dec, p. 1.

Eesti Teataja 1949. Paljasjalgne Tõnisson Siiamis. [Barefoot Tõnisson in Siam.] 20 Aug, p. 6.

E-mistika 2007. Available at http://www.e-mistika.lv/?txt=494, last accessed on 14 Apr 2008.

Esmaspäev 1927. Kõnelus punases mantlis mehega: Mis arvab Buddha munk Tõnisson Eestist: "Paljasjalgne" Tõnisson taarausuliste juures. [Conversations with a man in red coat. What Buddhist monk Tõnisson thinks of Estonia: "Barefoot" Tõnisson among the Taara-Believers.] 15 Aug, p. 3.

Esmaspäev 1929. Paljasjalgne Tõnisson hoidku oma nahk! [Barefoot Tõnisson save his skin!] 4 March, p. 3.

Esna, Olaf 2006. Bosonogii Tenisson [Barefoot Tõnisson]. Piarnuskii Ekspress, 2 June, p. 13.

Falke, Robert 1903. Buddha, Muhamed, Kristus: Nende isikute ja uskude võrdlus. Transl. by H. Oras. Tallinn: G. Pihlaka rmtkpl. Original: R. Falke 1898. Christentum und Buddhismus. Berlin: F. Rühe.

Fenzl, Friedrich 1985. Der Buddhismus in Russland in Vergangenheit und Gegenwart. Bodhi Baum, 10, pp. 91-100. 
Fišere, Ilze 1990. Latvietis Kārlis Augusts Tennisons - budas priesteris. [Latvian Karlis Augusts Tennisons - the Buddhist priest.] Riga: Grāmata, 2, pp. 89-92.

Fišere, Ilze 1998. Latvietis Kārlis Augusts Tennisons - Budas priesteris. [Latvian Karlis Augusts Tennisons - the Buddhist priest.] Literat ūra. Māksla. Mēs, 19-23 March. Gerodnik, Gennadi 1973. Vend Vahindra: Satiiriline dokumentaaljutustus. [Brother Vahindra: A satirical documentary.] Tallinn: Eesti Raamat.

Gori 1930. Prohvet Karlis Tennisons (caricature). Esmaspäev, 23 June, p. 8.

Grigoriantz, Alexandre 2004. Le Gorou de la Riviera. Paris: Jean-Claude Lattés.

Hallik, Martin 2001a. Orientalia Tartuensia: Idamaade ajalugu ja orientaalkeeled Tartu ülikoolis 1919-1940. [Orientalia Tartuensia: Oriental history and languages at the University of Tartu in 1919-1940.] Akadeemia, Vol. 3, pp. 572-582.

Hallik, Martin 2001b. Tartu ülikooli õppejõudude ja kasvandike osast humanitaarorientalistikas 1802-1940. [On the role of lecturers and students of the University of Tartu in Oriental studies in the humanities 1802-1940.] Dissertationes Historiae Universitatis Tartuensis, 4. Tartu: Tartu Ülikool.

Hallik, Martin \& Klaassen, Olaf-Mihkel 2002. Keiserlik Tartu Ülikool (1802-1918) ja Orient. [Tsarist University of Tartu (1802-1918).] Tartu: Tartu Ülikooli Kirjastus.

Hariduse Rahvakomissariaadi Teataja 1940. Avalikest ja koolide raamatukogudest kõrvaldamisele kuuluvate raamatute nimestik nr. 4. [Books to be confiscated from public and school libraries. List No. 4.] 8, pp. 99-110.

Hecker, Hellmuth 1997. Lebensbilder deutscher Buddhisten: ein bio-bibliographisches Handbuch. Band II: Die Nachfolger. Konstanz: Univ., Forschungsprojekt "Buddhist. Modernismus".

Hedin, Sven A. 1910. Himalaja takka: Piltidega / Sven Hedin'i reisikirjadest. [Transhimalaya: Discoveries and Adventures in Tibet.] Tallinn: Tallinn Eesti Kirjastuseühisus.

Hedin, Sven A. 1911. Tiibet.[Tibet.] Tallinn: M. Antje.

Hedin, Sven A. 1932. Seiklused Tiibetis. [Discoveries and Adventures in Tibet.] Tartu: Loodus.

Hedin, Sven A. 1939. Minu elu maadeavastajana. [My Life as an Explorer.] Tartu \& Tallinn: Loodus.

Hiis 1931. Hiie põhikiri. [Constitution of the Sacred Grove.] 3, pp. 67-72.

- i 1 - 1921. Paljasjalgne Tõnisson. [Barefoot Tõnisson] Vaba Maa, 1921, 4 March, p. 3.

Imelik, Olaf 1988. Võimatud võimalused. [Impossible possibilities.] Tallinn: O. Imelik.

The International Buddhist News Forum 1962. No decomposition of Latvian Archbishop's body: Miracle attributed to years of holy life, 2 (6/8), p. 32.

Issakov, Sergei 1983. Arhiivide peidikuist.[From hidden archives.] Tallinn: Eesti Raamat.

Janeks, Aleksandrs 1924. Ka Tennisons maldina publiku! [How Tennisons deceives his audience!] Rīgas Ziņas, 10 Dec.

Jõulu, Kaleph 2003. Ma tundsin Vend Vahindrat. [I knew Brother Vahindra.] Nädaline, 31 Dec, p. 20. 
Kaasaegne 1962. Mõni rida Kārlis Tennisons'ist. [Notes on Kārlis Tennisons.] Eesti Hääl, 6 July, p. 4.

Keyserling, Hermann von 1989. Bodhisattva - inimsoo ideaal. [Bodhisattva: Ideal of Humankind.] Sõnumitooja, 7/8, p. l.

Keyserling, Hermann von 1998. Loov tunnetus. [Creative cognition.] Tartu: Ilmamaa.

Klaassen, Olaf-Mihkel 1990. Aasia ja Aafrika 1918-1945 ning kontaktid Eestiga, l. [Asia and Africa 1918-1945 and Contacts with Estonia, Vol. 1] Tartu: Tartu Ülikool.

Kruus, Rein 1983. Märkmeid revolutsioonijärgsest vene nõukogude kirjandusest. [Notes on Post-Revolutionary Russian Soviet Literature.] Sõna 6: Noorte loomingut. Tallinn: Perioodika, pp. 58-73.

Kubbo, Alf 1967. Tsaarikullist kolme leopardini: mälestustegondliga kauge mineviku sadamais ja Vaba Eesti onnistuses... [From the Tsarist hawk to three leopards.] Toronto: Ortoprint.

Laane, Toomas 1983. "Vend Vahindra." Aja Kiri, 3 (27), pp. 31-33.

Laurisaar, Riho 2005. Paljasjalgne Tõnisson seikleb jälle [New adventures of Barefoot Tõnisson.] Eesti Päevaleht, 30 April, pp. 20-21.

Lao-Tse 1937. Dao-De-Džing: (Tao-Te-King). Tallinn: B. Parm.

Liiv, Joosep 1912. Budda ja Kristus. [Buddha and Christ.] Ristirahva Pühapäevaleht, No. 1, Tallinn: Ristirahva Pühapäevalehe kirjastus.

Liivaku, Uno 1995. Eesti raamatu lugu. [Estonian book history.] Tallinn: Monokkel.

Listopadov, Nikolay 2000. Pushkin v buddiiskom monastyre. [Pushkin in Buddhist Monastery.] Nauka i religiia, No. 2, pp. 16-18.

Lustig, Friedrich V. 1965. The Mahatma of Baltic: The remarkable life of the Most Rev. Kārlis A. M. Tennisons [n.d.] The Buddhist Archbishop of Latvia. [Manuscript held at the Estonian Archives in Australia].

Läänemets, Märt 2001. Budoloog Otto Rosenberg ja Eesti. [Budologist Otto Rosenberg and Estonia.] Tuna, 1, pp. 66-75.

Mahatma Vend-Vahindra 1930. Mina ja minu jüngrid usume nõnda. [Me and my disciples believe so.] Riga: Kārlis Tennisons (Tartu: Ed. Bergmann).

Majak, Richard 1975. Tee tuli endal leida.[You had to find the way.] Tallinn: Eesti Raamat.

Mengel, Hamilkar 1962. Täiendavat K. Tennisonsist. [Additional information on K. Tennisons.] Vaba Eesti Sõna, 4 Oct, p. 4.

Mereste, Uno 2003. Toimunust ja kaasaelatust I: Meenutusi aastaist 1928-1964. [On past events and experiences, Vol. 1: Recollections from 1928-1964.] Tallinn: SE \& JS.

Mäll, Linnart 1989. Ületava mõistmise südasuutra: Sissejuhatavad märkused. [Perfection of Wisdom Heart Sutra: Introductory remarks.] Ex Oriente. Tallinn: Perioodika, pp. 8-12.

Mäll, Linnart 1998. Nulli ja lõpmatuse kohal. [At zero and infinity.] Eesti mõttelugu. Tartu: Ilmamaa.

The Nation (Rangoon) 1958. Buddhist Archbishop of Latvia is 85 years old, 65 years a priest: Devotion to life concept, code of values; servise without personal benefits. Aug 10.

The Nation (Rangoon) 1962. Dalai Lama condoles Latvian prelate's end. 20 May. 
Niitme, Arno 1983. Noorus ja kooliaastad Treffoonias. [The youth and school years in Hugo Treffneri Gymnasium.] California.

Nurmekund, Pent (ed.) 1968. Kratkii ocherk istorii vostokodevedeniia v Tartuskom universtitete. Töid orientalistika alalt $1=$ Trudy po vostokovedeniiu $1=$ Oriental studies 1. Tartu Riikliku Ülikooli Toimetised, 201. Tartu: Tartu Riiklik Ülikool, pp. 5-12.

Olcott, Henry Steel 1916a. Budda usu katekismuse esimene peatükk: Eestikeelde trükkida lasknud Budda usuline munk Karl Augustus Mihailovitsh Tennisson [Chapter One of the Buddhist catechism that Karl Augustus Mikhailovich Tennisson had published in Estonian.] 1916. Tartu: Hermann. Original: H. S. Olcott 1881. A Buddhist Catechism: According to the Sinhalese Canon. First ed., Madras.

Olcott, Henry Steel 1916b. Budda usu katekismuse esimene peatükk, mida Zeiloni saare ülempreester H. Sumangala läbi kutsunud ja heaks kiitnud. Eesti-keelde trükkida lasknud Budda usuline munk Karl Augustus Mihailovitsh Tennisson. [Chapter One of the Buddhist Catechism that H. Sumangala, Grand Priest of the Ceylon Island, has tested and approved / Published in Estonian by Buddhist Monk Karl Augustus Mikhailovich Tennisson.] Tallinn: M. Schiffer. Original: H. S. Olcott 1881. A Buddhist Catechism: According to the Sinhalese Canon. First ed. Madras.

Olcott, Henry Steel 2002. Budistlik käsiraamat. Transl. into Estonian by Virve Külaviir. Tallinn: H. P. B. Loož.

Oma Maa 1930. Mahatma Wend-Wahindra näitusel: Andis intervjuu meie lehe esitajale. [Mahatma Brother Wahindra on the exhibition: Interview with the editor.] 14 Sept, p. 9.

Ossendowsky, Ferdynand 1924. Loomad, inimesed ja jumalad. Beasts, Men and Gods. Transl. into Estonian by Ella Jung. Tallinn: Tallinna Eesti Kirjastus-Ühisus.

Palm, August 1960. Eesti pseudonüümid. I valik. [Estonian pseudonyms. 1st selection.] Tartu: Eesti NSV Teaduste Akadeemia Fr. R. Kreutzwaldi nim. Kirjandusmuuseum. Manuscript.

Postimees 1923. Cand. theol. J. Albrecht. 9 Nov, p. 5.

Postimees 1927a. Buddha õpetus: Buddha ja Kristuse eetika võrdlus. [Buddhist teaching: Comparison of Buddhist and Christian ethics.] 10 April, p. 4.

Postimees 1927b. Ettevõtlikud üliõpilased:Tahtsid Buddhausu munga pealt teenida. [Entrepreneurial students: Wished to make money on a Buddhist monk.] 8 Oct. p. 7.

Postimees 1928a. Paljasjalgne Buddha preester Tartus. [Barefoot Buddhist priest in Tartu.] 6 May, p. 7.

Postimees 1928b. Käik Buddhapreestri palvekotta: Kolm tähtsat asja: vesi, tuli ja lilled. [A visit to the temple of a Buddhist priest: Three main things: water, fire and flowers.] 9 Sept, p. 5.

Pruuli, Tiit 2005. Burma - the Land I Love. Visioon [Special issue of Äripäev], 22 June, pp. 40-42.

Pruuli, Tiit \& Vähi, Peeter 2007. Tuhandenäoline budism. [Buddhism with its thousand faces.] [Tallinn]: Tammerraamat.

Põlenik, Ave 2004. Budismist Eestis. [Buddhism in Estonia] Mitut usku Eesti. [1]. Tartu: Tartu University Press, pp. 67-95.

Päss, Elmar 1939. Death, burial and life beyond the grave with the Estonian Ingers and the Votes. Akadeemilise Orientaalseltsi kirjutised $2=$ Scripta Academicae Societatis Orientalis 2. Tartu: Akadeemiline Orientaalselts. 
Päevaleht 1932. Vend Vahindra Bangkokis. [Brother Vahindra in Bangkok.] 12 Feb, p. 1.

Päevaleht 1933.Tenison palvetab Siiamis Läti eest. [Tenison prays for Latvia in Siam.] 21 March, p. 3.

Päevaleht 1936. Kinnitati kaks uut akadeemilist seltsi. [Two new academic societies registered.] 8 Jan, p. 5.

Päevaleht 1939. Kultuurisidemetesse Kaug-Idaga. [Cultural ties with the Far East.] 17 July, p. 7.

Raamatukogu 1923. G. Pihlakase kirjastusel ilmunud raamatud. [Books published by G. Pihlakas' Publishers.] l, pp. 60-61.

Raamatukogudest $1963=$ Raamatukogudest ja antikvariaatidest kõrvaldamisele kuuluvate kodanlikul ja okupatsiooni ajal Eestis ilmunud väljaannete koondnimekiri, 2. [Final list of books published during the bourgeois periood and the period of occupation in Estonia confiscated from libraries and second-hand bookstores] 1963. Tallinn: s.n.

Raamatukogudest $1966=$ Raamatukogudest ja antikvariaatidest kõrvaldamisele kuuluvate kodanlikul ja okupatsiooni ajal Eestis ilmunud väljaannete koondnimekiri, 2. [Final list of books published during the bourgeois periood and the periood of occupation in Estonia confiscated from libraries and second-hand bookstores] 1966. Tallinn: s.n.

Rahvaleht 1925. "Paljasjalgse" Tõnissoni juures külas: Kuidas õppis prohvet ka talvel paljajalu käima. [A visit to "barefoot" Tõnisson: How the prophet learned to walk barefoot in winter.] 18 Aug, p. 4.

Rahvaleht 1927. Buddha usu preester Tõnisson Tallinnas. [Buddhist priest Tõnisson in Tallinn.] 13 Aug, p. 3.

Rahvastik 1935 = Rahvastiku koostis ja korteriolud: 1 . III 1934 rahvaloenduse andmed. 1935. [Population and accommodation: Data of 1934 census, 1 March 1934], 2. Tallinn

Raoberg [!], Vladimir 1927. Toimetusele saadetud kiri. [Letter to editor.] Postimees, 9 Oct, p. 7.

Raudla, Heiki 2001. Vend Vahindra ja tema jünger. [Brother Vahindra and his disciple.] Sakala Kalender 2002. Põltsamaa, pp. 63-73.

Rawlinson, Andrew 1997. The Book of Enlightened Masters: Western Teachers in Eastern Traditions. Chigaco \& La Salle: Open Court.

Remsu, Olev 1998. Vend Vahindra: Täispika mängufilmi stsenaariumi esildis. [Brother Vahindra: Proposition of the script of a full feature film.] Sirp, 4 Sept, p. 17.

Remsu, Olev 1999. Kindralleitnant Robert Roman Ungern-Sternberg: Hiiumaa parun, kellel oli maailma suurim varandus ning kes tahtis vallutada Euroopa. [General lieutenant Robert Roman Ungern-Sternberg: Baron of Hiiumaa who owned the greatest fortune in the world and wanted to conquer Europe.] Haapsalu: V. Pinn.

Rootalu, Anu 1990. Kaks suutrat. [Two sutras.] Heinakuu, No. 1, pp. 46-47.

Rumor-Ast, Karl 1930. Palava päikese ja fanaatilise usu maal: Reisikirjad Tseilonist ja Indiast. [On the land of hot sun and religious fanatics.] Tartu: Loodus. 
Simm, Aleksander 1962. Veel paljasjalgsest Tõnissonist. [More on Barefoot Tõnnisson.] Meie Elu, $30 \mathrm{Aug}$, p. 2.

Staël von Holstein, Alexander \& Keyserling, Hermann 1991. India-reisid. [Travels in India.] Loomingu raamatukogu, Vols. 9-10. Tallinn: Perioodika.

Tallinna 1927 = Tallinna Eesti Kirjastus-Ühisus "Päevalehe" raamatukaupluste raamatute nimekiri 1928. [1928 list of books in Päevaleht bookstores.] Tallinn: Eesti Kirjastajate ja Raamatukaupmeeste Ühing.

Stockholms-Tidningen Eestlastele 1949. Paljasjalgse "peapiiskopi" tegevus Siiami pealinnas. [Activities of the barefoot "arch bishop" in the capital of Siam.] 13 Dec.

Stockholms-Tidningen Eestlastele 1950. Paljasjalgne Tõnisson saadeti koos jüngriga Siiamist Burmasse. [Barefoot Tõnisson and his disciple was exiled from Siam to Burma.] 19 March, p. 2.

Strauss, Carl Theodor 1929. Buddha ja tema õpetus. [Buddha and his teachings.] Tartu: Sõnavara.

(The Sunday) Nation 1961. The Buddhist Archbishop of Latvia Observes Double Anniversary: 68 Years in Buddhist Priesthood: Saintly Life is Known Far and Wide. 13 Aug.

Sõnumitooja 1990. Akadeemilise Orientaalseltsi ilmumata jäänud... [Unpublished materials of the Academic Oriental Society.] 3, p. 3.

Säde 1906. Buddha. 11 March, 13 March, 14 March.

Tallinna Teataja 1910. Peterburist. [Of St Petersburg.] 19 Nov, p. 2.

Talts, Mait 1998. Vend Vahindra - ainuke eesti rahvusest pühak. [Brother Vahindra: the only Estonian saint.] Laupäevaleht, 15 Aug, pp. 4-5.

Talts, Mait 1999. Mälestuseks. [In commemoration.] Eesti Päevaleht (Tallinn), 23 Aug, p. 6.

Talts, Mait 2002. Punases mantlis mees: 40 aastat Vend Vahindra surmast. [The man in a red coat: 40 years after the death of Brother Vahindra.] Eesti Päevaleht (Stockholm), 3 May, p. 7.

Talts, Mait 2003. "Esimene buda preester Baltimere rannikul...": Karl August Tennison ja eestlaste esmatutvus budismiga I [Original Estonian text]. Akadeemia, No. 7, p. 1424-1444.

Talts, Mait 2004. Veidi valgust hämarkohtadele Vend Vahindra elus [Some light shed on the shaded spots in Brother Vahindra's life.] Viljandi Muuseumi Aastaraamat 2003. Viljandi: Viljandi Museum, pp. 85-98.

Teder, Anne \& Mõttus, Raivo 1993. Vend Vahindra: Balti budismi isa - Eesti pühak? [Brother Vahindra: Father of the Baltic Buddhism - Estonian saint?] Maagiline Maailm, 10, pp. 5-11.

Teder, Juhan 1973. Vend Vahindra Viljandis. [Brother Vahindra in Viljandi.] Tee Kommunismile, 17 Feb, p. 3.

Tennisson, Karl 1909a. Tennissoni elulugu: Luuleteel 306 salmi. [Tennisson's life story: poetic career of 306 verses.] Tallinn: s.n.

Tennisson, K. A. 1909b. Uchenie o tom, kak chelovek sdelaetsia bezsmertnym. [A teaching of how to immortalise a human.] Riga: s.n. 
Tennisson, Karl August 1911a. Suur meister Buddha ja tema kõrgemoraaliline õpetus: Velikii meister Buddkha i ego vysoko-moralnoe uchenie. [The Great Master Buddha and his noble moral teachings.] Tallinn: s.n.

Tennisson, Karl August 1911b. Inimene. [The man.] Tallinn: Keyler ja poeg.

Tennisson, Karl 1913a. Igavene mälestus. [Eternal memory.] Tallinn: W. Volkmann [leaflet].

Tennisson, Karl 1913b. 10 zapoved $i=10$ bauschsi = 10 käsku [Ten commandments.] Riga [leaflet].

Tennisson, Karl August 1914. Mikspärast Buddha usulised juutide Talmudi ei usu? [Why can't Buddhists believe in Jewish Talmud?] Tallinn: s.n.

Tennison, Karl A. 1915. Igavene mälestus suurest Ilmasõjast, millest mina Karl Tennisson osa võttin. [Eternally remembering the Great World War which I, Karl Tennisson, took part in.] Tallinn.

Tennisson, K. 1916a. Ma Buddha jünger naeratan... [I, the follower of Buddha, am smiling.] Uusleht, 1 Sept, p. 2.

Tennisson, K. 1916b. Buddizm: Drevneindiiskaia religioznaia filosofia i ego evoliucia $v$ Evrope v nashi dni. Tallinn: s.n.

Tennisson, Karl A. M. 1916c. Laul Tormilinnust ehk minu elust. [The song about the Storm Bird, or my life.] Tallinn: M. Schiffer [leaflet].

Tennisson, Karl Augustus Mihailowitsh 1916d. Igawene mälestus suurest ilmasõjast, millest mina Karl Augustus Mihailowitsh Tennisson wabatahtlisena osa wõtsin. [Eternally remembering the Great World War which I, Karl Augustus Mihailowitsh Tennisson, volunteered for.] Tallinn: J. \& A. Paalmann [leaflet].

Tennisons, K. 1924. Latvijas budistu himna. [The anthem of Latvian Buddhists.] Rĭgas Ziņas, 8 Dec.

Tennisons, Karlis A. M. 1925. Buddas priesteris Tennisons g rib dot latvju tautai? [What Buddhist priest Tennison wishes to give to the people of Latvia?] Riga.

Tennisons, Karlis 1927. Hom-Mani-Patme-Hung. Tartu: Varrak.

Tennisons, K. A. M. 1954. Latvian Archbishop's Address at World's Buddhist Conference. The Nation (Rangoon), 10 Dec, pp. 3, 6.

Tennisons, K. A. M. 1959. The Baltic States' links with Buddhism. Aryan Path, 30 (2), pp. 52-55; (3), pp. 111-115.

Tennisons, Karlis A. M. 1962. Letter to the editor. The International Buddhist News Forum, Vol. 2, No. 3, pp. 7-8.

Tolstoy, Leo 1907. Tolstoi poolehoidmise vastu: Mõtteid Tolstoi seltsi kohta: Mõtteid muhamedi, "buddha" ja ristiusust: Usust ja uskmatusest. [Thoughts on Islamic, Buddhist and Christian Faith.] Tallinn: A. Peterson.

Tõnnisson, Karl A. M. 1907. Meie Maakera wiimased minutid. [The Last minutes of our Earth.] Riga \& Tallinn.

Tonska, Arnold 1962. Võitlus kuradiga: Veel mälestuskilde äsjasurnud Karlis Tennisonist. [Fighting with Devil: Shards of memory of recently departed Karlis Tennison.] Eesti Hääl, 20 July, pp. 2-3.

Täielik 1927 = Täielik Eesti raamatuturu kataloog. [Complete catalogue of Estonian book market.] Tallinn: Eesti Kirjastajate ja Raamatukaubastajate Ühing. 
Udam, Haljand 1997. Eestimaalane Mongoolias sõjajumalaks. [An Estonian war god in Mongolia.] Luup, No. 2, 20 Jan, pp. 48-50.

Udam, Haljand 1998. Budismi erilaadne fluidum. [The unique influence of Buddhism.] Postimees, 13 Sept, p. 5 = Udam, Haljand 2002. Budismi erilaadne fluidum. In: H. Udam. Maagid, filosoofid, poliitikud. [Magicians, philosophers, politicians.] Loomingu Raamatukogu Vol. 1-3. Tallinn: Perioodika, pp. 65-68.

Uudiste veste-osa 1904. Buddha, tema elu ja õpetus. [Buddha, his life and teachings.] pp. 79-82, 85.

Uus Eesti 1935. Asutati akadeemiline orientaalselts. [Academic Oriental Society was established], 11 Dec, p. 7.

Uus Eesti 1936. Budha munk Tõnisson Shanghais. [Buddhist monk Tõnisson in Shanghai.] 25 Feb, p. 7.

Uusleht 1916. Seda ja teist. [This and that.] 1 Sept, p. 2.

Vaba Maa 1920. Ennenägematu eeskava: Joh. Üksi naljamäng. [Incredible spectacle: Farce by Joh. Üksi.] 29 Nov, p. 1.

Vaba Maa 1927a. Paljasjalgne Tõnisson Tallinnas: Kümme aastat rännakut idas ja läänes: Balti riikides puudub pind buddha usule. [Barefoot Tõnisson in Tallinn: Ten years of travelling in the east and west: No grounds for Buddhism in the Baltic countries.] 12 Aug, p. 4.

Vaba Maa 1927b. Paljasjalgse Tõnissoni jutlus Tallinnas: Buddha usu levitamise katsel. [Sermon of barefoot Tõnisson in Tallinn: Attempts to disseminate Buddhism.] 30 Aug, p. 4.

Vaba Maa 1927c. Karlis Tennisons Bürgermusses kuradiga võitlemas: Buddha õnnistus "Postimehele" [Karlis Tennisons fighting with devil in Bürgermusse: Buddha's blessing to daily paper Postimees.] 1 Dec, p. 6.

Vaba Maa 1929. Paljasjalgne Tõnisson Eestit valgustamas: Algavad Tiibeti tantsud ja hiiemetsa palvetunnid: Vend Vahindra teeb konkurentsi taarausulistele. [Barefoot Tõnisson enlightening Estonia: The announcement of Tibetan dances and prayer sessions in the sacred grove: Brother Vahindra challenges Taara-believers.] 9 March, p. 2.

Vaba Maa 1930. "Vend Vahindra" Narva-Jõesuus: Karlis Tennisonsi paganausujutlused. [Brother Vahindra in Narva-Jõesuu. The pagan sermons of Karlis Tennisons.] 19 June, p. 6.

Vaba Maa 1931. Vend-Vahindra suvitab Itaalias. [Brother Vahindra spends his summer in Italy.] 11 July, p. 7.

Vaba Maa 1932. Vend Vahindra läkitus oma pojale vaimus Schwindrale. [Brother Vahindra's message to his son Schwindra in spirit.] 3 May, p. 2.

Vaba Maa 1935. Päikesekummardajad Karksis: Puusärgikaupmees asutas uue usulahu, mis peab ainsaks jumaluseks päikest. [Sun worshippers in Karksi: Coffin salesman founded a new sect which recognises Sun as their only god.] 23 Jan, p. 5.

Vaba Maa 1936. Eesti - armastuse maa: Mida tähendab "Eesti" hiinakeelne nimetus. Mida teadis Eestist Araabia geograaf 1154. aastal: 2 huvitavat ettekannet Tartus akad. orientaalseltsis. [Estonia - The Land of Love: How is 'Estonia' translated in Chinese. What did an Arabian geographer know about Estonia in 1154: Two interesting presentations at the Academic Oriental Society in Tartu.] 28 Feb, p. 4. 
Veem, Konrad 1988. Eesti vaba rahvakirik: Dokumentatsioon ja leksikon. [Estonian Free People's Church: Documents and glossary.] Stockholm: Eesti Vaimulik Raamat.

Vend Vahindra 1928. Tulevane Pan-Baltoonia Ilmariik ja selles kuldses riigis asuvate Buddha-, Päärkonsi-, Pikse- ehk Taarausu preestrite seadus. [The future Pan-Baltonia and the law of Buddhist or Taara priests in this golden state.] Riga: K. Tennisons.

Vend Vahindra 1993. Tulevane Buddhistlik Balti Riik. [The future Buddhist Baltic Country.] Tallinn: Buddhakirjastus.

Verzeichniß 1837 = Verzeichniß der vom 23. Julius bis zum 19. December $1837 \mathrm{zu}$ haltenden halbjährigen Vorlesungen auf der Kaiserlichen Universität zu Dorpat. Dorpat. 